\title{
1994 BASELINE BIOLOGICAL STUDIES FOR THE DEVICE ASSEMBLY FACILITY AT THE NEVADA TEST SITE
}

\author{
Edited By: \\ Yvonne E. Townsend
}

February 1995

Work Performed Under

Contract No. DE-AC08-94NV11432

Prepared for the

U.S. Department of Energy

Nevada Operations Office

Prepared by:

Reynolds Electrical \& Engineering Co., Inc.

Post Office Box 98521

Las Vegas, Nevada 89193-8521 



\section{DISCLAIMER}

This report was prepared as an account of work sponsored by an agency of the United States Government. Neither the United States Government nor any agency thereof, nor any of their employees, make any warranty, express or implied, or assumes any legal liability or responsibility for the accuracy, completeness, or usefulness of any information, apparatus, product, or process disclosed, or represents that its use would not infringe privately owned rights. Reference herein to any specific commercial product, process, or service by trade name, trademark, manufacturer, or otherwise does not necessarily constitute or imply its endorsement, recommendation, or favoring by the United States Government or any agency thereof. The views and opinions of authors expressed herein do not necessarily state or reflect those of the United States Government or any agency thereof. 


\section{DISCLAIMER}

Portions of this document may be illegible in electronic image products. Images are produced from the best available original document. 


\section{ACKNOWLEDGEMENTS}

We credit the following for help with field work: T. Ackerman, D. Bunn, L. Conte, B. Edwards, D. Henson, J. Hopkin, B. Pritchard, R. Ryu, and M. Treanor. Work was performed under contract number DE-AC08-94NV11432. Scientific collection permits were provided by the state of Nevada, Department of Wildlife (S 6404 and S 9022), and the U.S. Fish and Wildlife Service (PRT-744522). 


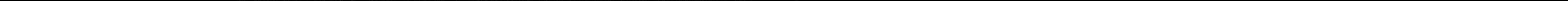




\section{TABLE OF CONTENTS}

Page

Acknowledgements $\ldots \ldots \ldots \ldots \ldots \ldots \ldots \ldots \ldots \ldots \ldots \ldots \ldots \ldots \ldots \ldots$ iii

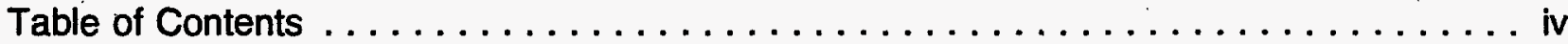

List of Figures $\ldots \ldots \ldots \ldots \ldots \ldots \ldots \ldots \ldots \ldots \ldots \ldots \ldots \ldots \ldots \ldots \ldots \ldots \ldots$

List of Tables ................................ vi

1.0 Executive Summary $\ldots \ldots \ldots \ldots \ldots \ldots \ldots \ldots \ldots \ldots \ldots \ldots \ldots \ldots \ldots \ldots \ldots$

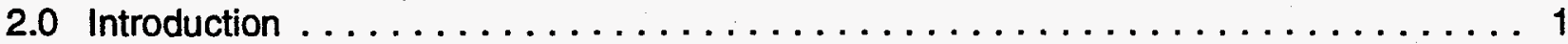

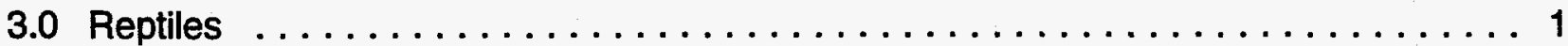

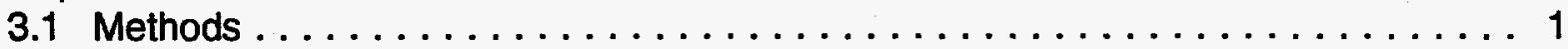

3.2 Results and Discussion . . . . . . . . . . . . . . . . . . 3

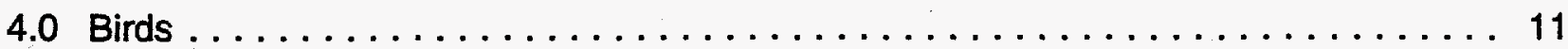

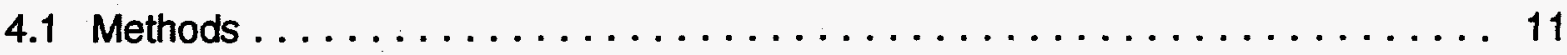

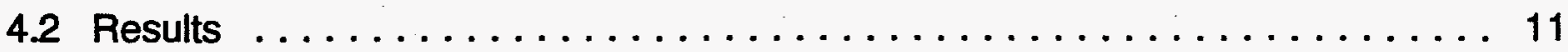

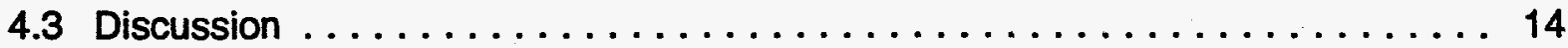

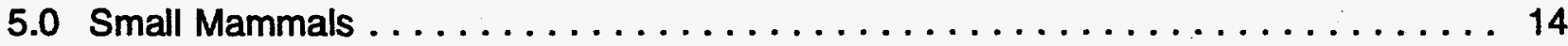

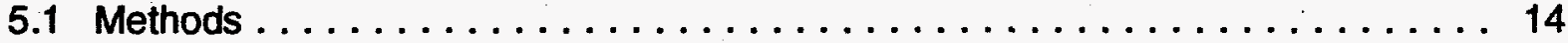

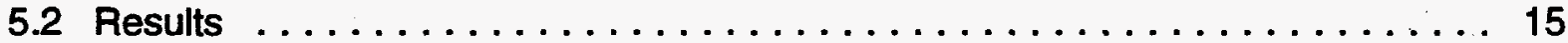

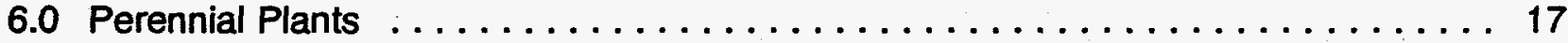

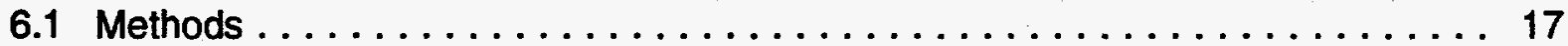

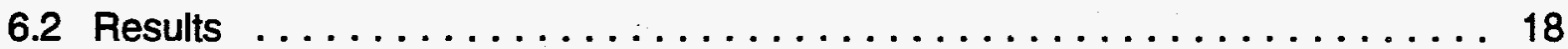

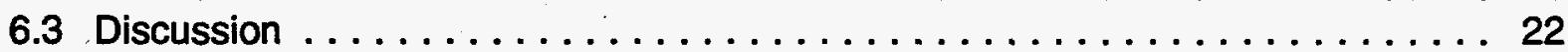

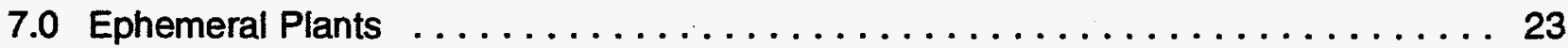

7.1 Methods .............................. 23

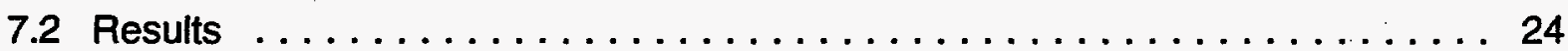

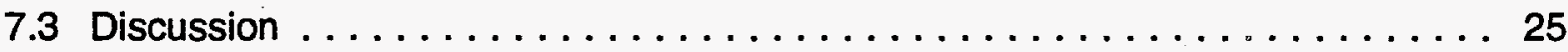

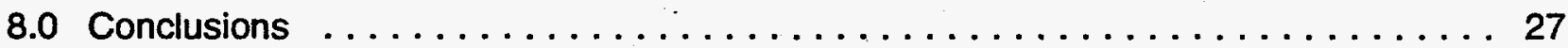

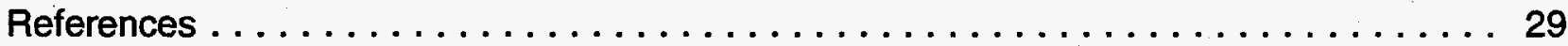

Distribution . . . . . . . . . . . . . . . . . . . . . 


\section{LIST OF FIGURES}

Page

Figure 1. Location of mammal and lizard study plots around the DAF . . . . . . . . 2

Figure 2. Number of uta/ha present on graded or vegetated plots near the DAF . . . . 4

Figure 3. Number of lizards present on graded or vegetated plots near the DAF . . . . . 4

Figure 4. Mean uta SVL on graded and vegetated plots near the DAF . . . . . . . 5

Figure 5. Mean uta weight on graded and vegetated plots near the DAF . . . . . . . 5

Figure 6. Mean uta age on graded and vegetated plots near the DAF . . . . . . . . . 6

Figure 7. Mean number of uta/ha observed on transects in graded and vegetated areas near the DAF . . . . . . . . . . . . . . . . . . . . . . . 6

Figure 8. Mean number of lizards observed on transects in graded and vegetated areas near the DAF . . . . . . . . . . . . . . 7

Figure 9. Number of lizard species seen per transect section in graded and vegetated areas near the DAF . . . . . . . . . . . . . . . . . 7

Figure 10. Number of whiptails seen per hectare in graded and vegetated areas near the DAF . . . . . . . . . . . . . 8

Figure 11. Number of uta/ha seen on transects on the four axes around the DAF . . . . 8

Figure 12. Number of lizards/ha seen on transects on the four axes around the DAF . . . . 9

Figure 13. Number of lizard species seen per transect section on the four axes around the DAF . . . . . . . . . . . . . . . . . . . . . . . . . 9

Figure 14. Number of uta/ha present on plots in graded and vegetated areas near the DAF in summer $1994 \ldots \ldots \ldots \ldots \ldots \ldots$. . . . . . . . . . . . . 10

Figure 15. Relative abundance of small mammals at the DAF in $1994 \ldots \ldots \ldots \ldots$

Figure 16. Relative abundance of small mammals at the DAF in $1993 \ldots \ldots \ldots \ldots$

Figure 17. Mean capture \pm 2 se per 10 stakes in early June 1993 and 1994 at the DAF 


\section{LIST OF TABLES}

Page

Table 1. Bird species observed at the DAF sewage pond during 1994; $N=17$ sampling dates (April-October); Percent frequency of occurrence $=$ number of sample dates a species was seen divided by 17 and

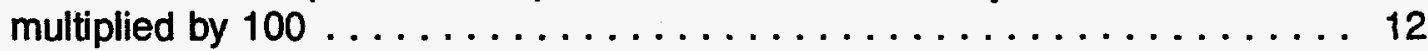

Table 2. Total and mean number of bird visits per hour at the DAF sewage pond across 15 dates by common passerine species during $1994 \ldots \ldots \ldots \ldots$. . . 13

Table 3. Small mammals captured in 1994 at two DAF locations . . . . . . . . . . . . 15

Table 4. Total live volumes (liters per $1000 \mathrm{~m}^{2}$ ) and numbers for perennial plant species found on one hundred $10-\mathrm{m}^{2}$ transects surrounding the DAF $\ldots . . .19$

Table 5. Changes in numbers of Erioneuron pulchellum, and dead grasses (dominated by Erioneuron pulchellum) at different distances from the DAF, 1993-1994

Table 6. Mean live size (liters \pm 2 se) and percent change in mean size of surviving Erioneuron pulchellum versus distance from the DAF, 1993-1994

Table 7. Changes in numbers and mean size (liters \pm 2 se) of Sphaeralcea ambigua versus distance from the DAF, 1993-1994

Table 8. Mean growth coefficients ( $k$, defined in methods) \pm 2 se versus distance from the DAF ........................... 21

Table 9. Vegetative parameters at different directions from the DAF, $1994 \ldots \ldots$. . . . 21

Table 10. Summary statistics on two $1000-\mathrm{m}^{2}$ control transects; Plot $10-5$ was at 1242 m south and $20-5$ was 1197 m north of the DAF . . . . . . . . . . . . . 24

Table 11. Summary statistics on two $1000-\mathrm{m}^{2}$ transects; DAF2 was on a scraped, graveled area southwest of the DAF, and plot 16-1 is on a scraped compacted area West of the DAF; DAF2 data are from the same location in 1993 and $1994 ;-$ = the two plots differ in this parameter in 1994 at $p<0.05 ;{ }^{\star \star}=p<0.01$, d.f. $=38$

Table 12. Ephemeral species present and approximate densities in five sampled areas near the DAF in April 1994 ( $p=$ present in $1000 \mathrm{~m}^{2}$; densities estimated by several different techniques) 


\subsection{EXECUTIVE SUMMARY}

Biological surveys of plants, reptiles, birds, and small mammals continued in 1994, with emphasis on examining spatial and temporal variation in these groups in the Device Assembly Facility (DAF) vicinity. The DAF was still in a preoperational phase in 1994. To date, the main ecological DAF impacts have been removal of the perennial plant community by grading (for the access road, the building sites, parking lots, and construction staging areas), and addition of water to the sewage settling ponds. Grading removed the plants (creating habitat for weedy plant species), and removed habitat for animals. Adding water to the sewage ponds increased bird use of the DAF area.

As in 1993, Uta stansburiana (uta) densities were lower in graded areas immediately surrounding the DAF building complex relative to largely undisturbed areas nearby. Uta densities were also lower in largely undisturbed areas southwest of the DAF relative to undisturbed areas to the northeast of the DAF building complex. No chuckwallas or live tortoises were seen within $400 \mathrm{~m}$ of the DAF building complex. The small mammal community to the southwest of the DAF building complex contained the same number of species and had a similar species diversity to the one northeast of the DAF building complex. This contrasted with 1993 results when the small mammal community to the southeast differed greatly from the one to the northwest. Bird densities were markedly lower in 1994 relative to 1993 , as they were test-site wide. Bird reproduction near the DAF was essentially nonexistent in 1994. Plant results were largely similar in 1993 and 1994. There was some evidence that preoperational DAF activities reduced plant growth near the facility. The results across all studied taxa suggest that the DAF is located in a transitional area with different floral and faunal communities on different sides. The ramifications of this for monitoring impacts are discussed.

\subsection{INTRODUCTION}

This report describes environmental work performed at the DAF in 1994 by the Basic Environmental Monitoring and Compliance Program (BECAMP). BECAMP initiated DAF studies in 1993 when study techniques were worked out and permanent plots were set up (Woodward et al., 1995). The DAF is located near the Mojave-Great Basin desert transition zone $27 \mathrm{~km}$ north of Mercury. The area immediately around the DAF building complex is a gentle slope cut by 1 to $3 \mathrm{~m}$ deep arroyos, and occupied by transitional vegetation (Beatley 1976). In 1994, construction activities were largely limited to work inside the perimeter fence. The DAF was still in a preoperational mode in 1994, and no nuclear materials were present. The DAF facilities were being occupied so there was water in the sewage settling pond, and the roads and lights were in use. Sampling activities in 1994 represent the first year in the proposed monitoring scheme (Woodward et al., 1995). The proposed biological monitoring plan gives detailed experimental protocols. Plant, lizard, tortoise, small mammal, and bird surveys were performed in 1994. Below we briefly outline procedures employed in 1994. Studies performed on each taxon are reviewed separately then summarized in a concluding section.

\subsection{REPTILES}

\subsection{METHODS}

Lizards and tortoises were the only reptiles sampled near the DAF in 1994. DAF lizard (25 to 29 July) plot surveys and summer transects (7-9 June) in the area immediately surrounding the DAF building complex shown in Figure 1. Plot surveys were performed on eight largely 


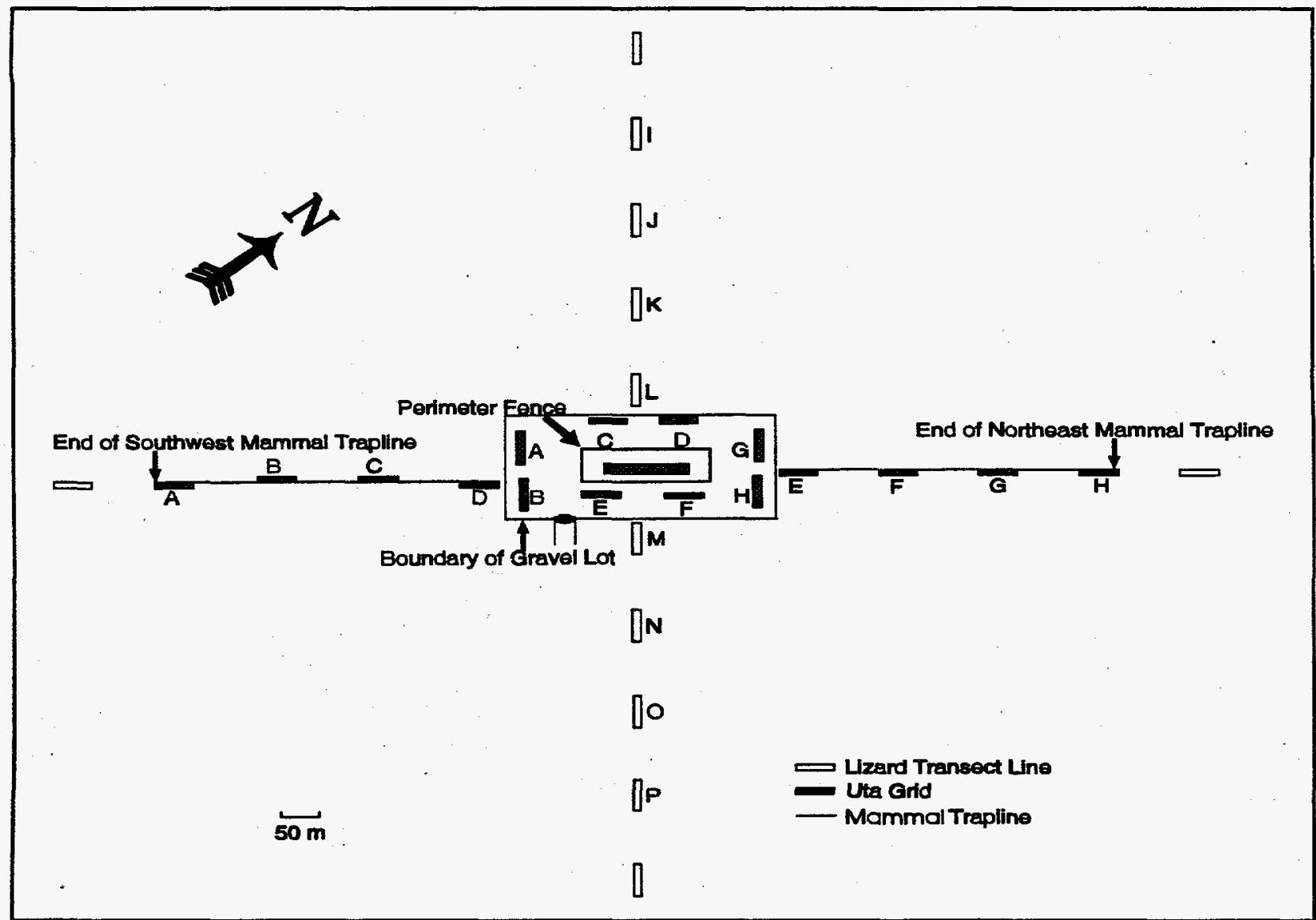

Figure 1. Location of mammal and lizard study plots around the DAF

undisturbed vegetated areas east and west of the DAF building (collectively called Plot FRF013) and eight cleared areas immediately surrounding this building (collectively called Plot FRF012). The 16 study areas or subplots were each 20 x 50 meters. Lizard surveys concentrate on uta because these lizards are abundant and widespread. Lizards were noosed, measured to the nearest $0.5 \mathrm{~mm}$ from snout to vent (SVL), weighed to the nearest $0.05 \mathrm{~g}$, marked and released at their capture locations. Uta ages were estimated from body size-age relationships of uta of known ages from areas near the DAF.

Mean number of uta or lizards (pooled across all species) were determined daily on each plot. Mean weight and SVL were calculated for all uta occupying each plot (sampled without replacement). Number of uta, number of lizards (pooled across all species), mean uta weight, and mean SVL were compared across graded and nongraded area with Mann-Whitney $U$ tests (MWU). The relative numbers of males and females (the sex ratio) was compared between graded and vegetated areas with a chi-square test.

Transect studies consisted of three investigators walking abreast and recording the number of each lizard species present on the transect. The transect was composed of $15 \times 50 \mathrm{~m}$ segments located in each subplot in FRF012 and FRF013, plus an additional $15 \times 50 \mathrm{~m}$ segment on the end of each arm going away from the DAF building (Figure 1). Counts of number of uta, number of lizards (pooled across all species), or number of species were compared between the graded area near the DAF building and the nongraded vegetated area with a MWU. A Kruskal-Wallis-Wilcox (KWW) test was used to compare number of uta, number of lizards, or number of species across the four arms of the sampling array. Results are reported in figures as mean \pm 2 se. 


\section{Tortoises and Chuckwallas}

A circular area approximately $1 \mathrm{~km}$ in diameter and centered on the DAF building complex was searched for tortoises and chuckwallas in September 1994. Two investigators walked back and forth in a systematic fashion about $7 \mathrm{~m}$ apart looking for these species. Tortoise remains were marked with aluminum stakes and left in place.

\subsection{RESULTS AND DISCUSSION}

In the spring, uta, Phrynosoma platyminos (horned-toads) and Callisaurus draconoides (zebratailed lizards) were seen on cleared plots, while uta, Sceloporus magister (desert spiny lizards) and Dipsosaurus dorsalis (desert iguanas) were seen on vegetated plots. Only uta were abundant enough to merit analysis as an individual species. Number of uta/plot ( $M W U=0, P=0.001$ ) or lizards/plot ( $M W U=0, P=0.001$ ) were greater on vegetated plots relative to cleared plots (Figures 2 and 3$)$. Although SVLs (MWU $=25.0, P=0.126$ ) and weight ( $M W U=26.0, P=0.089$ ) did not differ between control and treatment plots, there did appear to be a tendency for the few lizards on cleared areas to be larger and presumably older (Figures 4 and 5). Uta ages did not differ between control and treatment areas ( $M W U=22.0, P=0.307$, Figure 6). Sex ratios differed between the cleared and vegetated area (Fisher Exact probability test, $P=0.049$ ) with about as many males (41) as females (49) on the vegetated area, but more males (4) than females (0) on the cleared area. Transect studies revealed sizeable differences in lizard numbers between the graded area and the vegetated areas. There were more uta on vegetated plots relative to cleared areas ( $M W U=372, P=0.0001$, Figure 7 ). Similarly there were both more individual lizards ( $M W U=383, P=0.0001$, Figure 8 ) and more lizard species per plot $(M W U=384$, $P=0.0001$, Figure 9 ) in the vegetated area relative to the cleared areas. Number of whiptails/plot did not differ between cleared and vegetated areas ( $M W U=648, P=0.110$, Figure 10). Because of the circular layout, transect counts could be compared across the four cardinal directions. Number of uta/hectare (ha), (KWW $=14.13, P=0.003$, Figure 11) number of lizards/ha (KWW $=19.32, P<0.0001$, Figure 12), and number of lizard species/plot (KWW $=16.48, P=0.001$, Figure 13) all differed across the four cardinal directions, with western and southern arms of the array containing fewer uta, lizards, or lizard species. In the summer, two uta and three zebra-tailed lizards were seen on the cleared plots. In contrast, 58 uta, three zebra-tailed lizards, six Cnemidophorus tigris (whiptails), four horned-toads, and one desert spiny lizard were seen on the control plots. There were more uta/plot on the vegetated plots relative to the disturbed plots (MWU $=0.00, P=0.001$, Figure 14) suggesting that construction activity around the DAF complex has lowered uta densities. This effect appears to be due to vegetation removal. A similar result was obtained for comparisons of areas along roadsides that lacked perennial vegetation and nearby vegetated control areas near the DAF in 1993 (Woodward et al., 1995). Uta snout-vent lengths ( $M W U=26.5, P=0.186$ ), body weights ( $M W U=15.5, P=0.08$ ), and ages ( $M W U=26.5, P=0.178$ ) did not differ between the control and disturbed areas. This lack of statistical significance may reflect the extremely small number (2) of uta on the disturbed areas. Sex ratios were also similar on the control and disturbed areas (control area 30 males, 28 females; disturbed area 1 male, 1 female, Fisher Exact Probability $=0.737$ )

The lizard studies suggest that removing perennial vegetation around the DAF complex has had a detrimental effect on uta, essentially removing them from this area. Other lizards were also largely lacking, although sample sizes for these species were too small to merit analysis. The sizeable spatial variation (in number of uta, number of lizards, or number of lizard species) on the four sides of the DAF mean that the different lines were not good estimators of each other at least in 1994. Timed lizard surveys in 1993 (Woodward et al., 1995) 

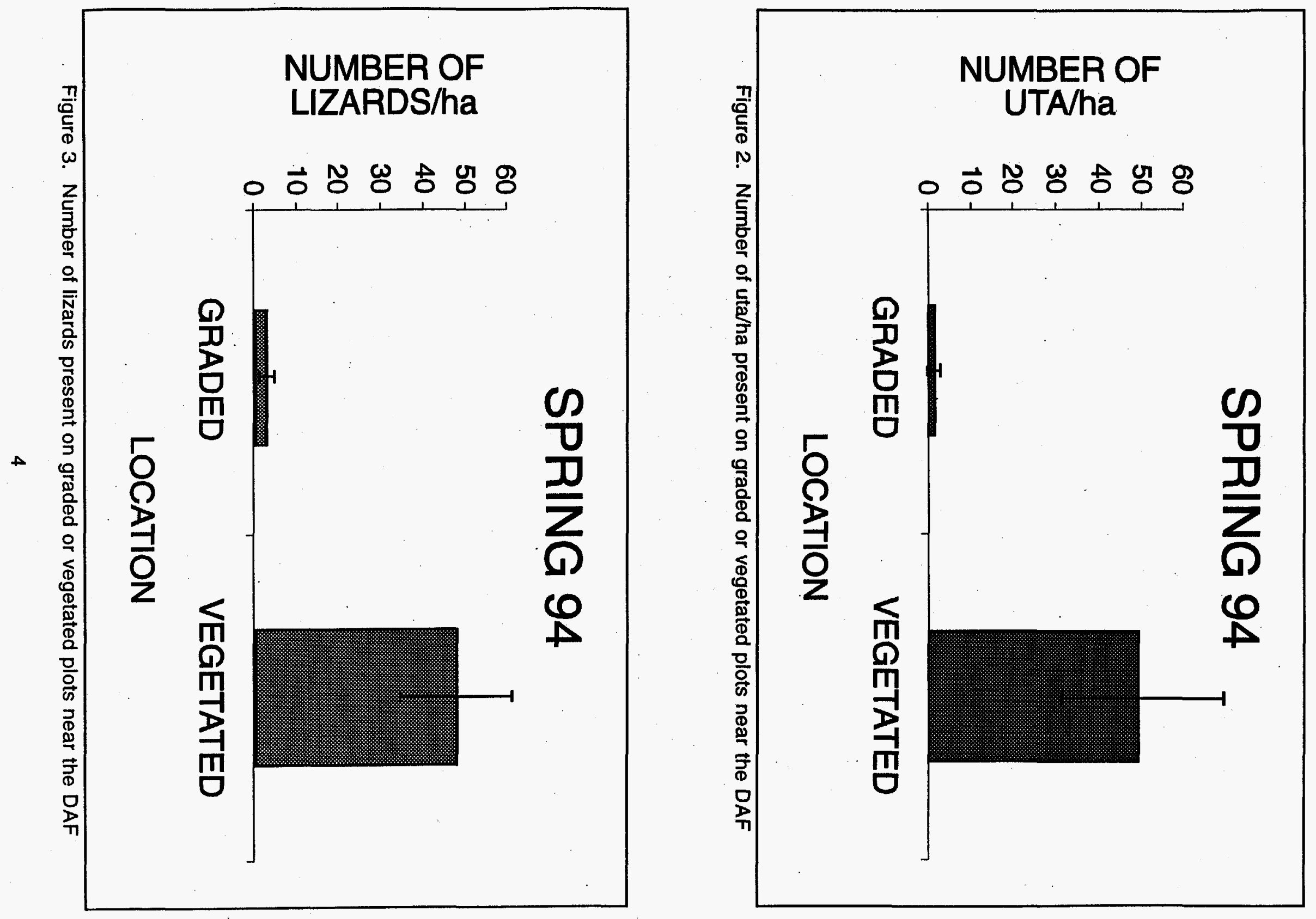


\section{SPRING 94}

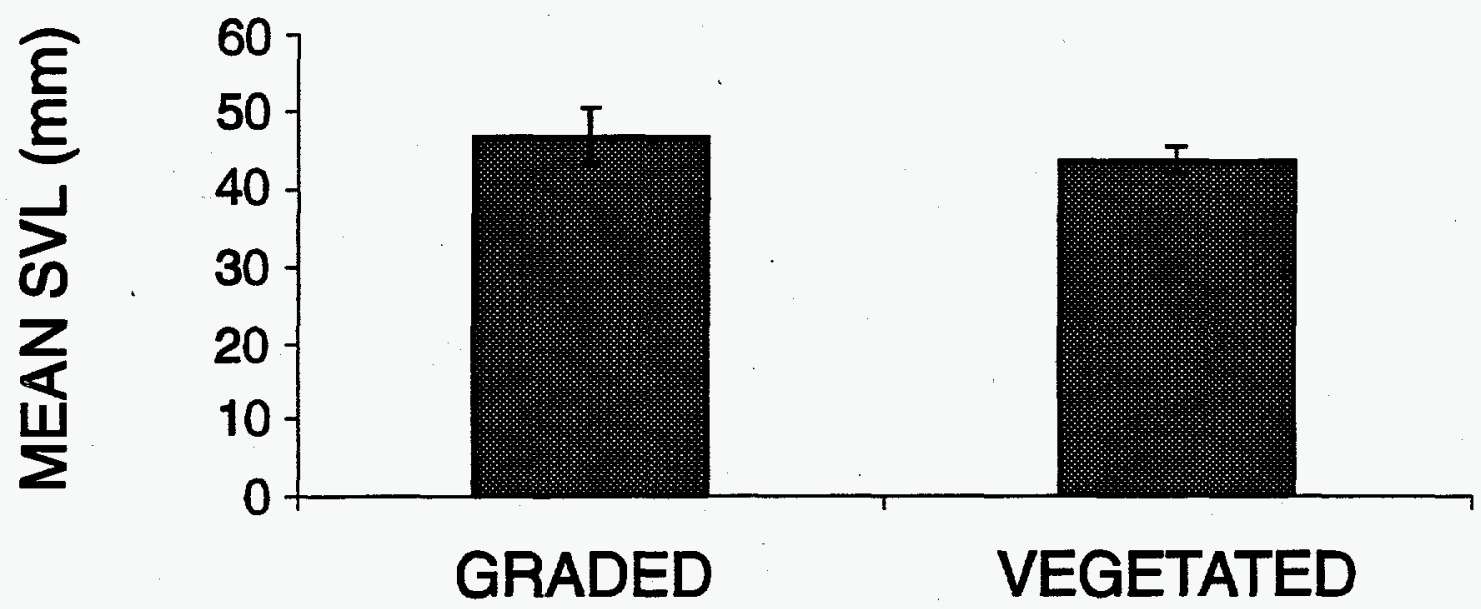

LOCATION

Figure 4. Mean uta SVL on graded and vegetated plots near the DAF

\section{SPRING 94}

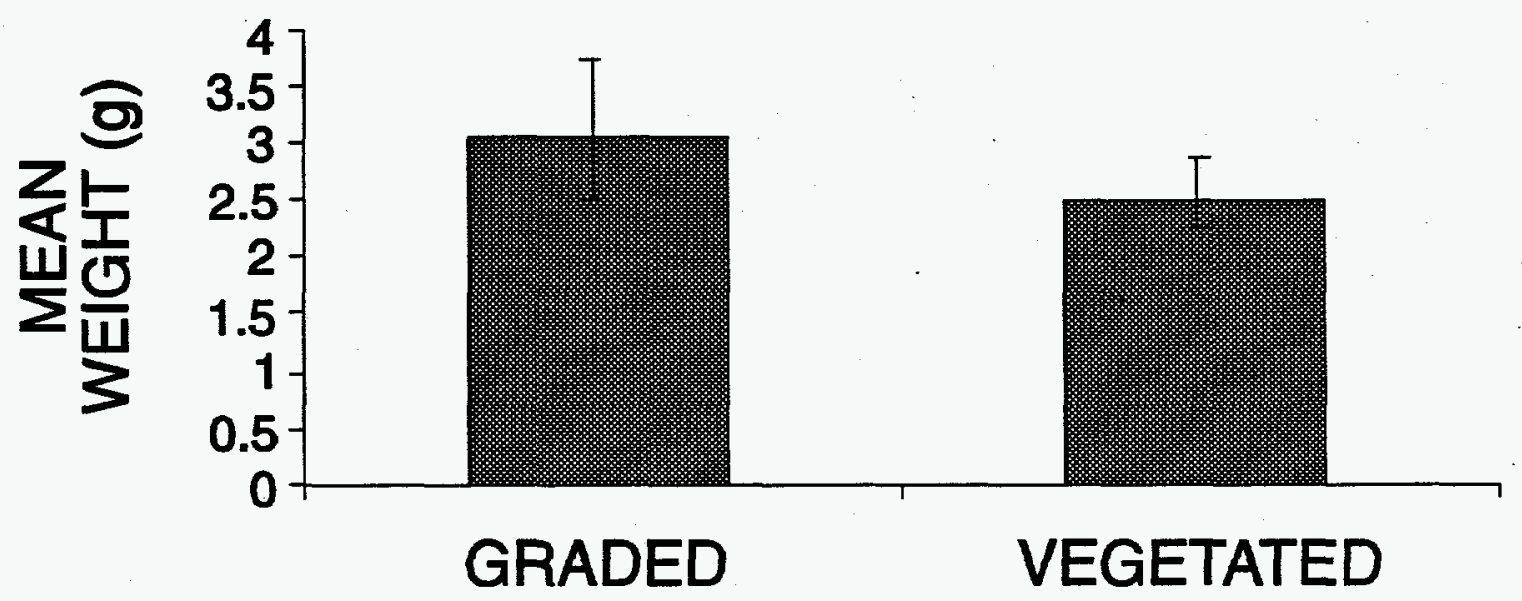

LOCATION

Figure 5. Mean uta weight on graded and vegetated plots near the DAF 


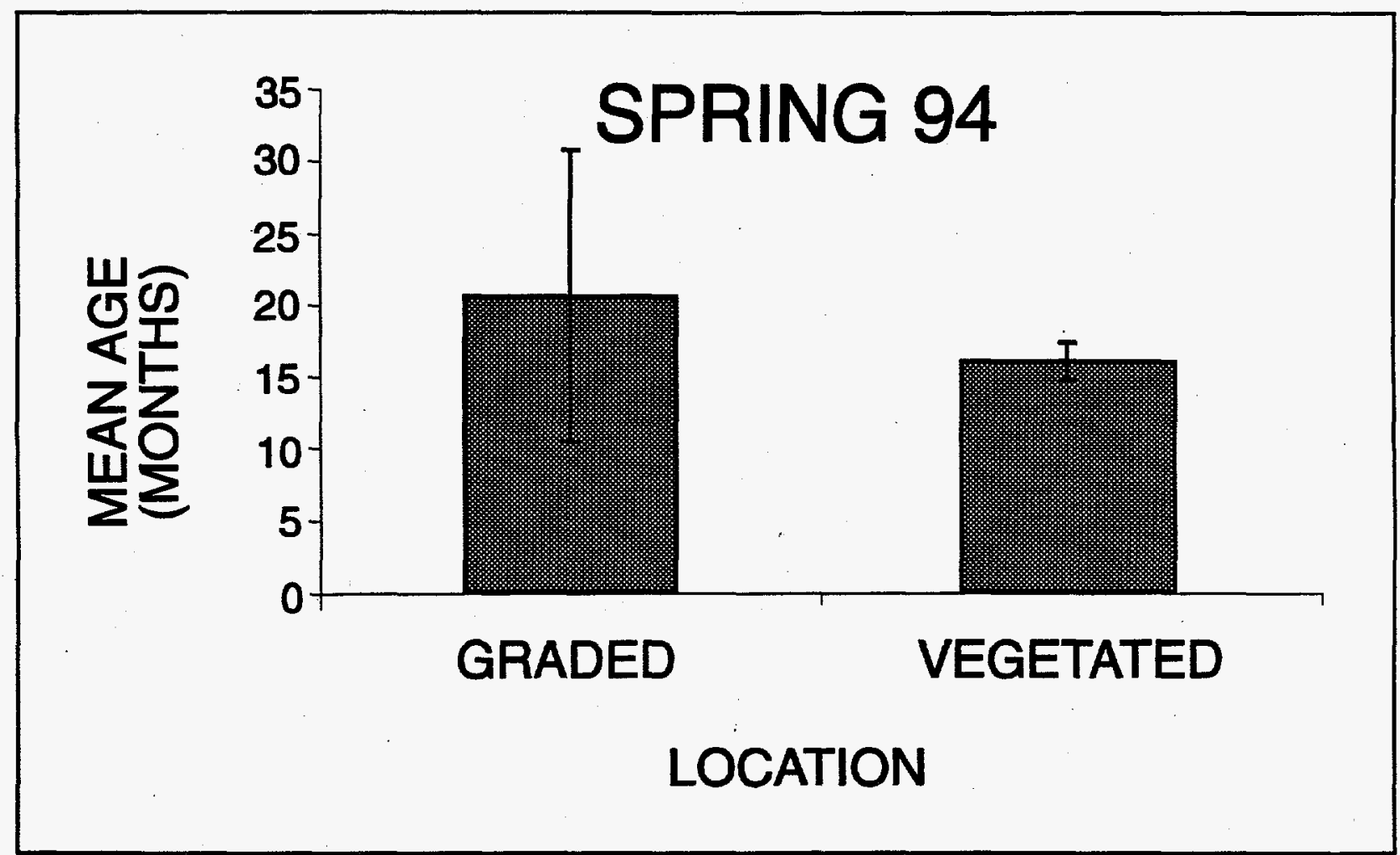

Figure 6. Mean uta age on graded and vegetated plots near the DAF

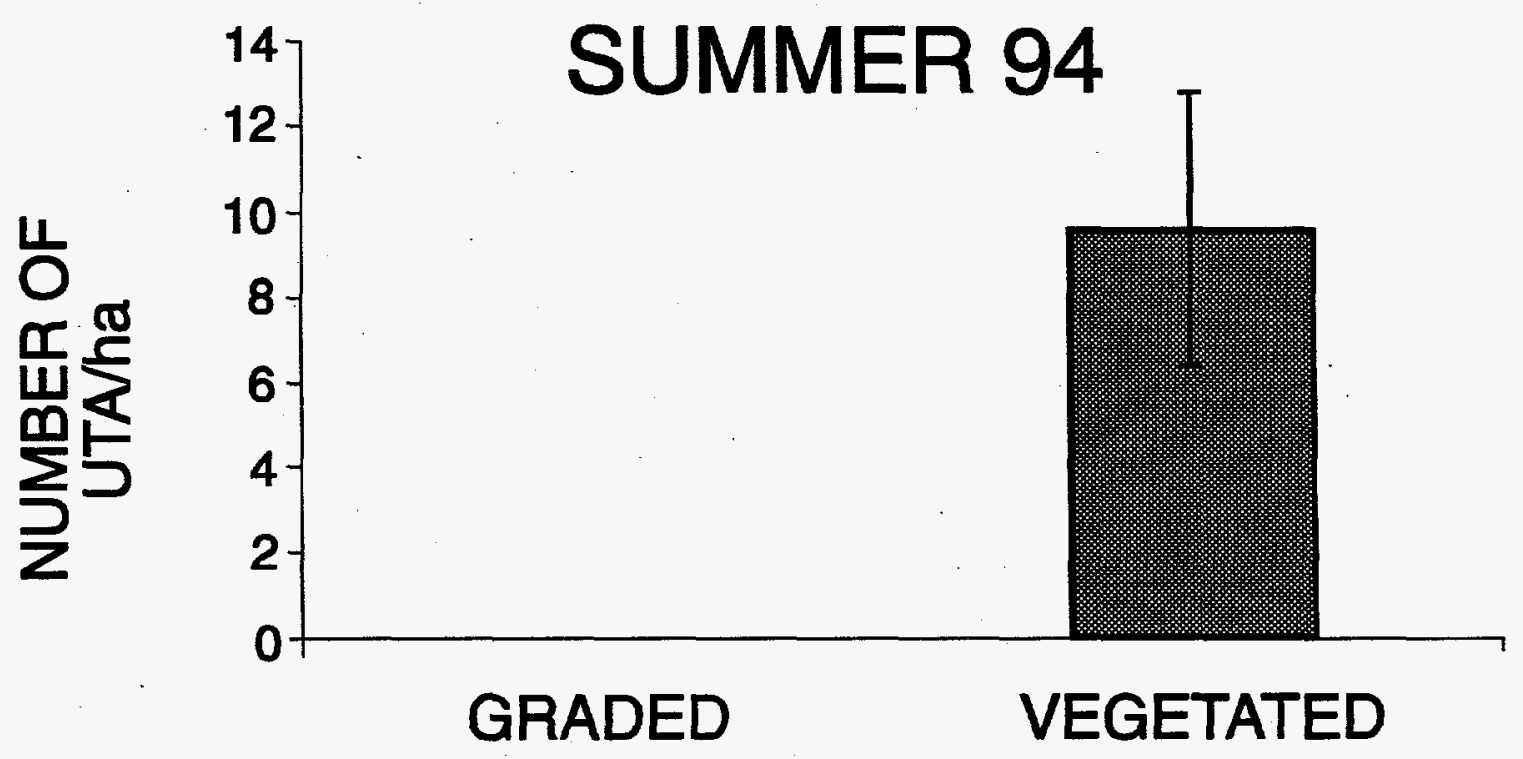

LOCATION

Figure 7. Mean number of uta/ha observed on transects in graded and vegetated areas near the DAF 


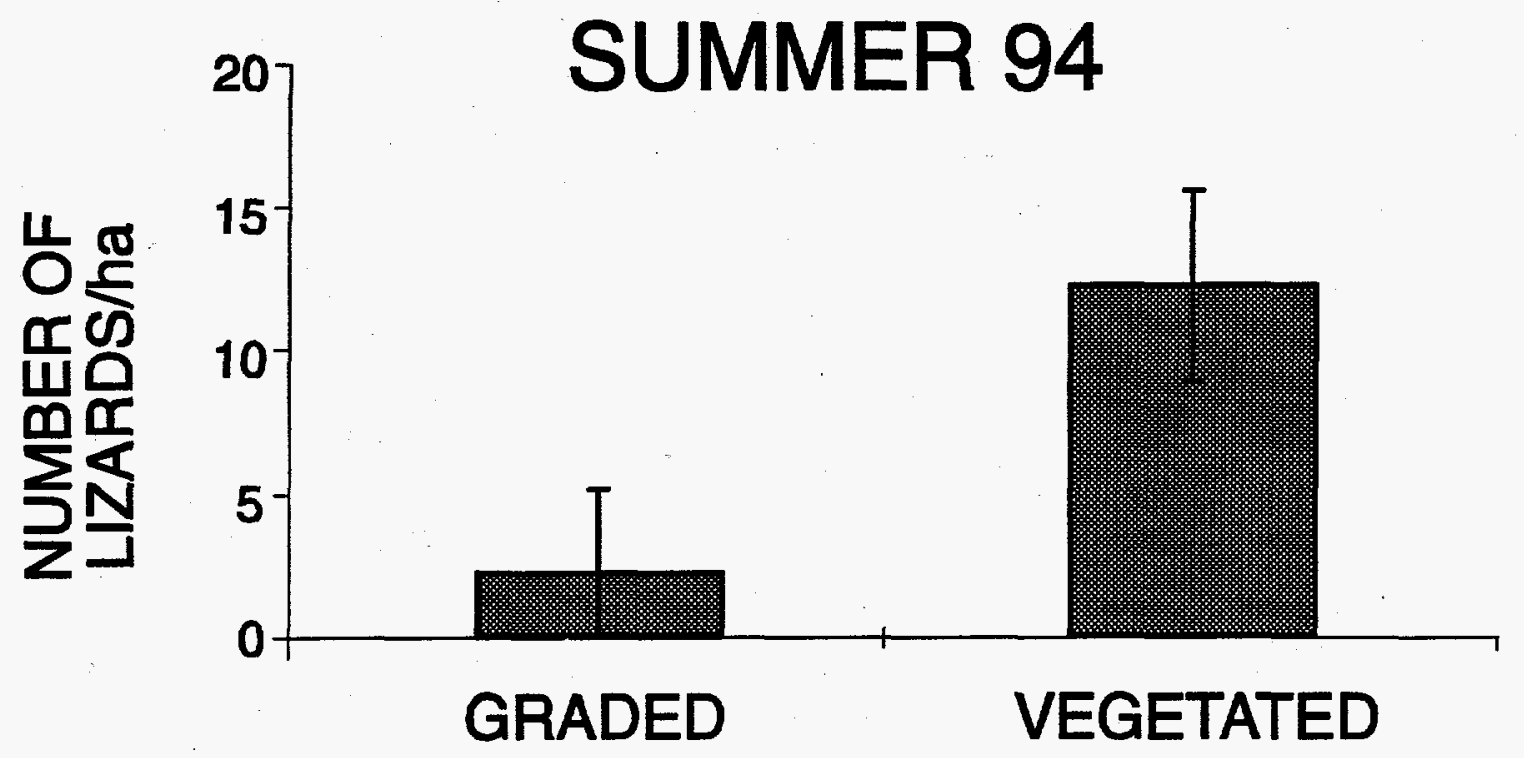

LOCATION

Figure 8. Mean number of lizards observed on transects in graded and vegetated areas near the DAF

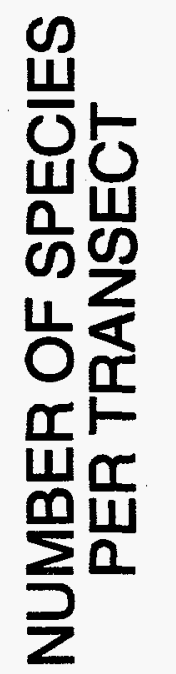

0.9

0.8

0.6

0.5

0.4

0.3

0.2

0.1

0

GRADED

VEGETATED

\section{LOCATION}

Figure 9. Number of lizard species seen per transect section in graded and vegetated areas near the DAF 

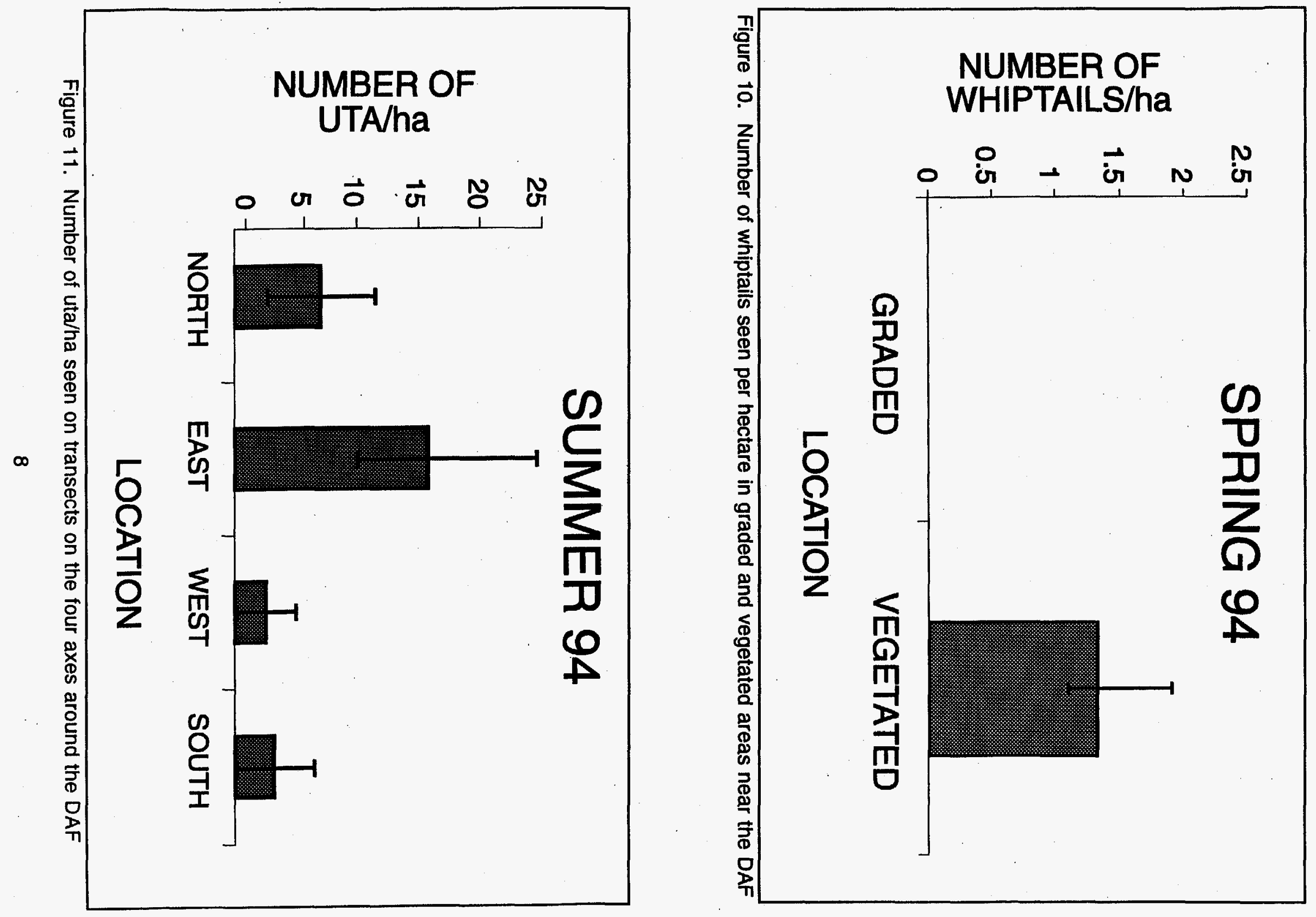

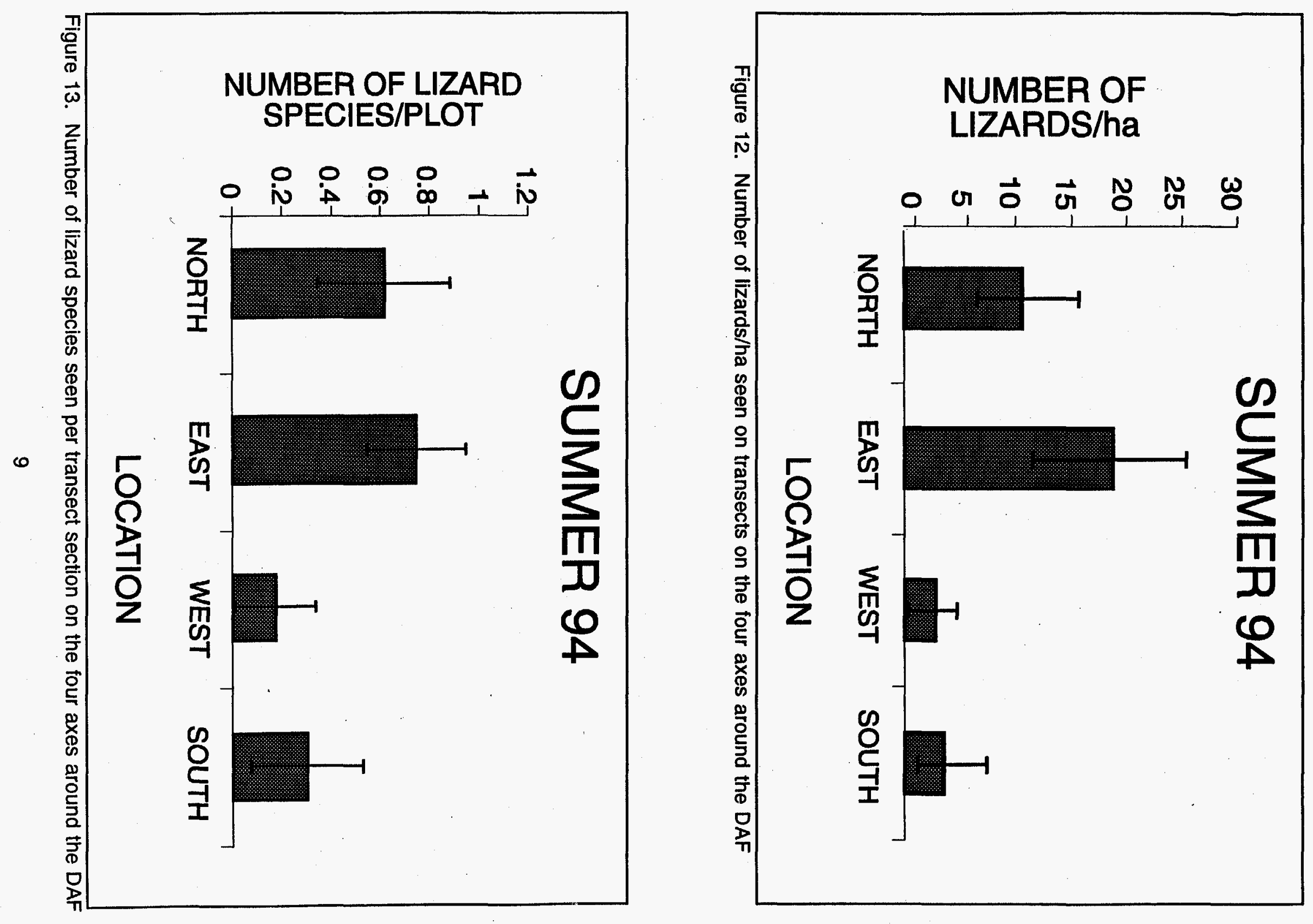


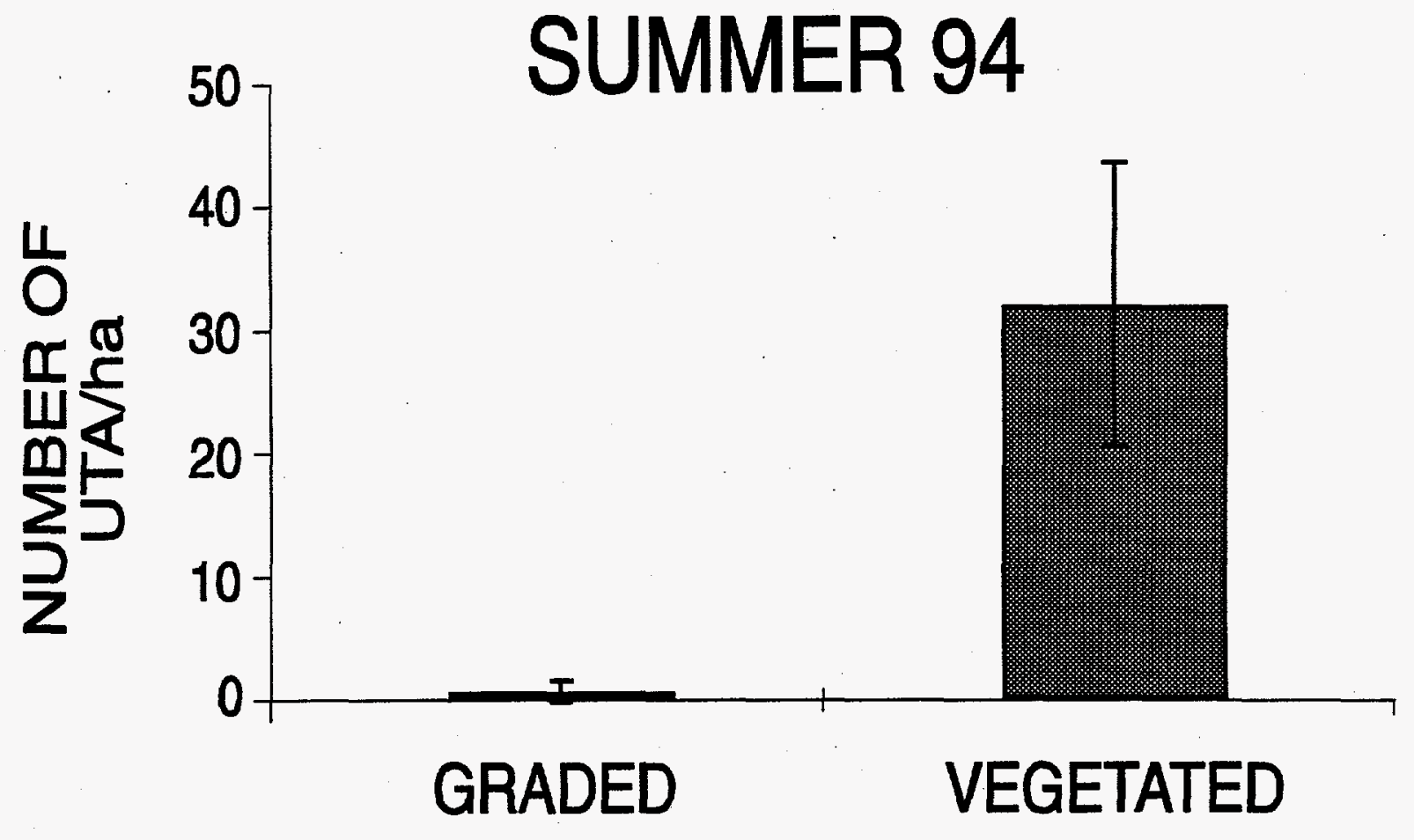

\section{LOCATION}

Figure 14. Number of uta/ha present on plots in graded and vegetated areas near the DAF in summer 1994

also suggested that areas to the south of the DAF tended to contain relatively few lizards. This difference means that detecting a directional DAF effect (arising from something like a nuclear accident and downwind drift of nuclear material) will be more difficult, because one cannot simply compare the downwind estimates to estimates from the other arms of the sample array. Instead, detection of this sort of effect will require comparisons of differences in estimates in prior surveys to differences after the directional DAF effect occurred. Because of this result it is suggested that plot studies be extended from looking at two arms of the array every third year, to examining all four arms of the array every year.

\section{Tortoises and Chuckwallas}

Two investigators looked for tortoises and chuckwallas for 35 manhours in an area $1 \mathrm{~km}$ in diameter centered on the DAF building complex. No chuckwallas were seen. No live tortoises were seen in 1994. In 1993, only one live tortoise was seen (twice). Seven sets of tortoise skeletal remains (old partial skeletons) were seen in this circular area in 1994. Tortoises appear to use this area infrequently. 


\subsection{BIRDS}

\subsection{METHODS}

\section{Sewage Pond Effects}

Bird use at DAF sewage ponds was recorded from April to October to assess effects of the presence of this sewage pond. The pond provided unlimited water availability to birds of the region, which otherwise would be limited. Pond use was estimated by recording bird visits per hour. Most birds were flushed from the pond area before a count began. A visit occurred when an individual entered, spent some time and left the area of the pond or its sloping banks. Birds were counted in 12 consecutive five-minute intervals at the sewage pond. Counts were recorded between 0800 and $1300 \mathrm{~h}$.

\section{Natural Habitat Sampling}

The variable-circular-plot technique (Reynolds et al., 1980; see Woodward et al., 1995, for methods details) was implemented in 1994 to estimate bird density. Eight plots were searched on eight dates between April 6 and June 16, 1994. The black-throated sparrow, Amphispiza bilineata was chosen for initial monitoring efforts because it was locally abundant. Numbers of nests, eggs, hatchlings, and fledglings were recorded during field efforts on two plots (6 ha) staked off at 50-m intervals. One was located near the DAF sewage pond and another $1 \mathrm{~km}$ south of the pond. These plots were set up initially to determine if the sewage pond might increase the local breeding bird density compared to a plot distant from the pond. The plot areas were initially searched in early May to determine onset of breeding for the region. The plots were searched for nests three times each from the end of May to the middle of June. Some opportunistic searches were also made for nests in additional areas around the DAF in May-June.

\subsection{RESULTS}

During seventeen visits to the DAF sewage pond in 1994 we observed 35 species of birds (Table 1). Bird numbers were very low in 1994 compared to 1993, as indicated by total counts (Table 1) as well as by low numbers of bird visits per hour (Table 2). The most frequently occurring birds at the sewage pond were killdeer, spotted sandpiper, house finch, Say's phoebe, and common raven based on percent frequency of occurrence (Table 1). Many species had low frequency of occurrence (<12 percent), indicating they were observed on only one or two sample dates. The most abundant birds observed were unidentified teal (37) and the above listed species excluding Say's phoebe.

Total number of bird visits to the DAF sewage pond are given in Table 2. Numbers were very low in comparison to counts made during 1994. A mixed flock of juvenile and adult brownheaded cowbirds was observed at the DAF sewage pond on July 18 indicating that reproduction had occurred nearby. Total bird visits for all species combined averaged less than 6 birds per hour over the period of study (Table 2).

\section{Birds in Natural Habitats at the DAF}

Bird species breeding near the DAF facility in 1994 included house finches, black-throated sparrows, loggerhead shrikes, and ash-throated flycatchers. Repeated searches for nests in the two 6-ha areas were made but none were found. Only two house finch nests were located in the region, both of which were outside the 6-ha plots. On May 19, 1994, one of the nests had three hatchlings and one had three bluish eggs. Only one juvenile was known to fledge from both nests combined. Both house finch nests were located in cholla 


\begin{tabular}{|c|c|c|}
\hline $\begin{array}{l}\text { Bird speciles observed } \\
\text { dates (April-October); } P \\
\text { dates a species was se }\end{array}$ & $\begin{array}{l}\text { during } 1994 ; \mathrm{N} \\
\text { ence }=\text { number } \\
\text { plied by } 100\end{array}$ & $\begin{array}{l}17 \text { sampling } \\
\text { ff sample }\end{array}$ \\
\hline Species & Total Number & $\begin{array}{l}\% \text { Frequency } \\
\text { of Occurrence }\end{array}$ \\
\hline Blue-winged teal & 7 & 11.8 \\
\hline Gadwall & 5 & 5.8 \\
\hline American widgeon & 2 & 5.8 \\
\hline Ring-necked duck & 1 & 5.8 \\
\hline Turkey vulture & 1 & 5.8 \\
\hline Red-tailed hawk & 2 & 11.8 \\
\hline Snowy egret & 7 & 17.6 \\
\hline Killdeer & 15 & 41.2 \\
\hline Least sandpiper & 2 & 5.8 \\
\hline Spotted sandpiper & 20 & 52.9 \\
\hline Eared grebe & 1 & 5.8 \\
\hline Wilson's phalarope & 6 & 17.6 \\
\hline Mourning dove & 13 & 23.5 \\
\hline Western sandpiper & 10 & 5.8 \\
\hline Western kingbird & 8 & 23.5 \\
\hline Common raven & 15 & 41.2 \\
\hline Great-tailed grackle & 1 & 5.8 \\
\hline Ash-throated flycatcher & 3 & 5.8 \\
\hline Say's phoebe & 9 & 41.2 \\
\hline Black phoebe & 1 & 5.8 \\
\hline Yellow-headed blackbird & 1 & 5.8 \\
\hline Sprague's pipit & 1 & 5.8 \\
\hline American pipit & 3 & 11.8 \\
\hline Brown-headed cowbird & 15 & 11.8 \\
\hline Horned lark & 7 & 17.6 \\
\hline House finch & 36 & 47.1 \\
\hline N. rough-winged swallow & 2 & 5.8 \\
\hline Barn swallow & 2 & 5.8 \\
\hline Black-throated sparrow & 15 & 29.4 \\
\hline Yellow-rumped warbler & 2 & 5.8 \\
\hline Song sparrow & 3 & 5.8 \\
\hline Brewer's blackbird & 1 & 5.8 \\
\hline Savannah sparrow & 2 & 5.8 \\
\hline Sage sparrow & 3 & 5.8 \\
\hline Empidonax flycatcher & 1 & 5.8 \\
\hline Unidentified teal & 37 & 17.6 \\
\hline Unidentified duck & 1 & 5.8 \\
\hline Unidentified swallow & 2 & 5.8 \\
\hline Total & 263 & \\
\hline
\end{tabular}


Table 2. Total and m20n number of bird visits per hour at the DAF sewage pond across 15 dates by common passerine species during 1994

\begin{tabular}{|c|c|c|c|c|c|}
\hline Date & Mourning & House finch & Black & Common & Sage \\
\hline 4 April & 0 & 2 & 0 & 2 & 0 \\
\hline 11 May & 0 & 8 & 0 & 2 & 0 \\
\hline 17 May & 0 & 7 & 0 & 2 & 0 \\
\hline 25 May & 3 & 8 & 0 & 0 & 0 \\
\hline 31 May & 0 & 0 & 0 & 0 & 0 \\
\hline 7 June & 3 & 5 & 2 & 2 & 0 \\
\hline 13 June & 0 & 1 & 1 & 0 & 0 \\
\hline 6 July & 3 & 0 & 2 & 0 & 0 \\
\hline 18 July & 4 & 0 & 5 & 0 & 0 \\
\hline 26 July & 0 & 0 & 0 & 0 & 0 \\
\hline 11 August & 0 & 0 & 0 & 0 & 0 \\
\hline 17 August & 0 & 0 & 0 & 1 & 0 \\
\hline 13 September & 0 & 0 & 0 & 1 & 0 \\
\hline 27 September & 0 & 5 & 0 & 5 & 0 \\
\hline 20 October & 0 & 0 & 0 & 0 & 3 \\
\hline Mean \pm 2 se & $0.9 \pm 0.8$ & $2.4 \pm 1.6$ & $0.7 \pm 0.7$ & $1.0 \pm 0.7$ & $0.2 \pm 0.4$ \\
\hline
\end{tabular}

cacti. Black-throated sparrows also appeared to breed but in very low numbers. No nests with eggs or young were found, although several juveniles were observed in the region in late spring.

In June several cavities in Joshua trees were located that could have served as nesting sites for ash-throated flycatchers (which were observed nearby) or some other cavity nesting species. Fresh nest material was also found inside one cavity in a Joshua tree indicating that cavity nesting might have occurred. No fledgling ash-throated flycatchers were observed in 1994; however, some were observed in 1993. On June 16, two juvenile loggerhead shrikes were observed on bird plots about 1-2 km west of the DAF facility suggesting this species reproduced in the region during 1994. Some nonbreeding species observed in natural habitats around the DAF included cactus wren, Scott's oriole, lesser nighthawk, Say's phoebe, western kingbird, ladderback woodpecker, and common raven. The only species observed in 1994 not associated with the sewage ponds were Scott's oriole, cactus wren, lesser nighthawk and ladderback woodpecker.

\section{Variable-Circular-Plot}

While black-throated sparrows were commonly observed on plots and appeared fairly abundant around the DAF in 1994, an accurate estimate of density for this species could not be made. This is because birds were not singing on numerous sampling dates and were often located in small flocks on the ground and could easily go undetected. To implement the variable-circular-plot method it is necessary to locate and count birds using both sight and 
sound. Birds were often difficult to see because they did not perch prominently in 1994, as they did in 1993. Hence, the detectability of black-throated sparrows was lower in 1994, making comparisons of breeding density to previous years unreasonable.

\subsection{DISCUSSION}

Bird numbers around the DAF were much reduced over 1993. For comparison, total number of bird visits recorded at the sewage pond during 1993 averaged over 400 birds per hour (Woodward et al. in prep.), while in 1994 it averaged about five visits per hour. Most notable were reductions in the number of mourning doves observed. This species averaged about 367 birds per hour in 1993 and averaged about one bird per hour in 1994.

Similarly, fewer numbers of house finches (2.4) and black-throated sparrows (0.7) were observed at the sewage pond in 1994 compared to 35 and 40 per hour respectively in 1993. Juvenile black-throated sparrows were also abundant at the sewage pond during summer of 1993; however, in 1994, none were observed. It is clear from these data that numbers of birds present in an area can fluctuate by orders of magnitude from year to year. The fluctuations appear to be most related to changes in availability of moisture. While blackthroated sparrows appeared to be common, densities could not be estimated with any certainty in 1994. Overall breeding success of birds, however, appears to have been much lower based primarily on scant observations of nests and juveniles during spring and summer.

This year's data points out some of the difficulties associated with monitoring birds in deserts: namely, that large fluctuations in numbers make it difficult to assess impacts, and changes in detectability of birds make year-to-year comparisons of data untenable. The variable-circularplot method was used as an experimental technique at the DAF facility in 1993-94, and it appears to work well only in wet years to define basic information needs. In dry years the method is not suitable for desert environments.

In summary, the sewage pond at the DAF facility appears to benefit bird species in the region during periods of moisture availability, and equally benefits numerous species for migratory rest stops. Negative impacts of the sewage pond, if present, could not be measured. To minimize impacts on biota at the DAF facility, it is recommended that removal of vegetation for operations of the site be kept to a necessary minimum.

\subsection{SMALL MAMMALS}

Small mammal studies around the DAF focused on abundance and species diversity at two areas outside the DAF construction impact area. The 1993 baseline inventory of small mammals suggested a marked difference between the areas northwest and southeast of the DAF (Woodward et al., 1995). The 1994 study looked at the regions northeast and southwest of the DAF compound and was limited to one survey at each site.

\subsection{METHODS}

Methodology was similar to that in 1993 (Woodward et al., 1995). Small mammal traps (Sherman) were laid out on the lizard transect lines east and west of the DAF (Figure 1). Transect lines were $440 \mathrm{~m}$ long with stakes at $10-\mathrm{m}$ intervals. Two traps were placed near each stake (90/line), using available vegetation to shade traps from the morning sun.

Traps were baited on the evenings of May 31 and June 1,1994 , with a mixture of rolled oats and birdseed. Traps on the two 440-m lines were checked on June 1-2, 1994, and closed. 
Captured animals were identified to species, marked (or the identifying number read if a recapture), sexed, aged (adult or juvenile), weighed to the nearest gram, and released at the capture location.

In 1993, two types of traps were used: sheet metal (Sherman) and wire mesh (A thru Z Consulting and Distributing). The wire mesh traps were difficult to use, were without any added benefit, and were therefore not used in 1994.

\subsection{RESULTS}

\section{Rodent Abundance}

Small mammals and related parameters are summarized in Table 3. The two sites were virtually identical in total number of individuals, trap success, and species diversity. The distribution of individuals by species, however, was slightly different, but not significant $\left(x^{2}=0.893, P=0.345\right)$. Chaetodipus formosus was most abundant northeast of the DAF and Dipodomys merriami was most common southwest of the DAF (Figure 15). Physiography of the two sites accounts for the differences as the areas north and east of the DAF cut through several well defined washes. The areas west and south have a few small, indistinct washes. The vegetation is also sparser to the southwest.

No new species were captured around the DAF in 1994. Two species captured on 1993 traplines, Onychomys torridus and Peromyscus eremicus, were not captured in 1994 (Figures 15,16 ). Number of species per plot averaged $7.3 \pm 2.3$ (mean \pm 2 se) in early June 1993 $(\mathrm{N}=3)$ and $5.0 \pm 0.0$ in $1994(\mathrm{~N}=2)$.

Species diversity was slightly (but not significantly) higher on the northeast trapline than the southwest line $\left(t_{125}=0.962, P=0.338\right)$. Mean number of captures per 10 stakes (20 traps) were higher on 1994 traplines than in 1993 (Figure 17).

\begin{tabular}{|c|c|c|c|c|c|c|}
\hline & \multicolumn{3}{|c|}{ Northeast Trapline } & \multicolumn{3}{|c|}{ Southwest Trapline } \\
\hline & Number & $\% \mathrm{~T}$ & o1/? & Number & $\% T$ & $8 / 9$ \\
\hline Chaetodipus formosus & 31 & 47.7 & $16 / 15$ & 26 & 42.6 & $13 / 13$ \\
\hline Dipodomys merriami & 25 & 38.5 & $1.3 / 12$ & 30 & 49.2 & $18 / 12$ \\
\hline Dipodomys microps & 5 & 7.7 & $2 / 3$ & -- & -- & --- \\
\hline Perognathus longimembris & -- & -- & -- & 1 & 1.6 & $1 / 0$ \\
\hline Neotoma lepida & 3 & 4.6 & $2 / 1$ & 3 & 4.9 & $2 / 1$ \\
\hline Peromyscus maniculatus & 1 & 1.5 & $0 / 1$ & -- & -- & -- \\
\hline Ammospermophilus leucurus & -- & $\cdots$ & -- & 1 & 1.6 & $0 / 1$ \\
\hline Total Number Individuals & 65 & 100.0 & $33 / 32$ & 61 & 99.9 & $34 / 27$ \\
\hline Number of Species & 5 & & & 5 & & \\
\hline Species Diversity $\left(H^{\prime}\right)$ & 0.4882 & & & 0.4323 & & \\
\hline
\end{tabular}




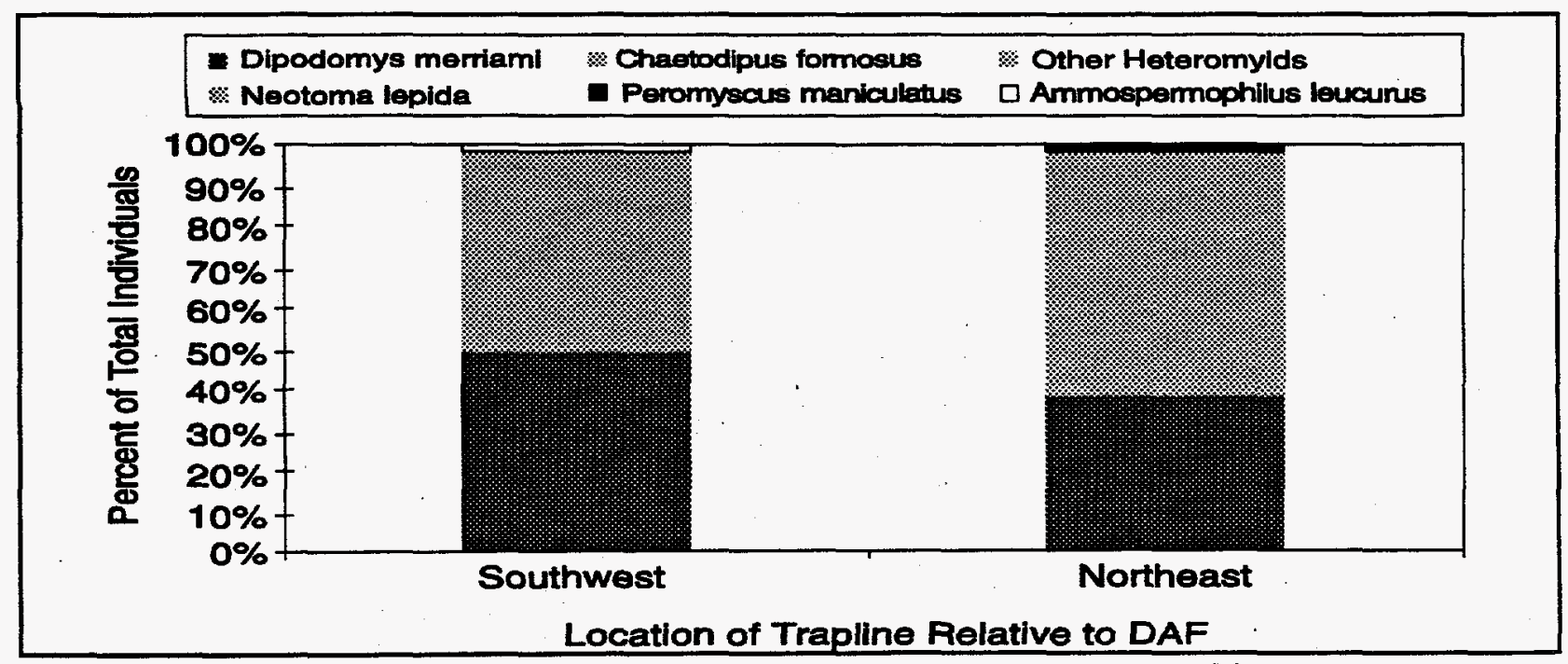

Figure 15. Relative abundance of small mammals at the DAF in 1994

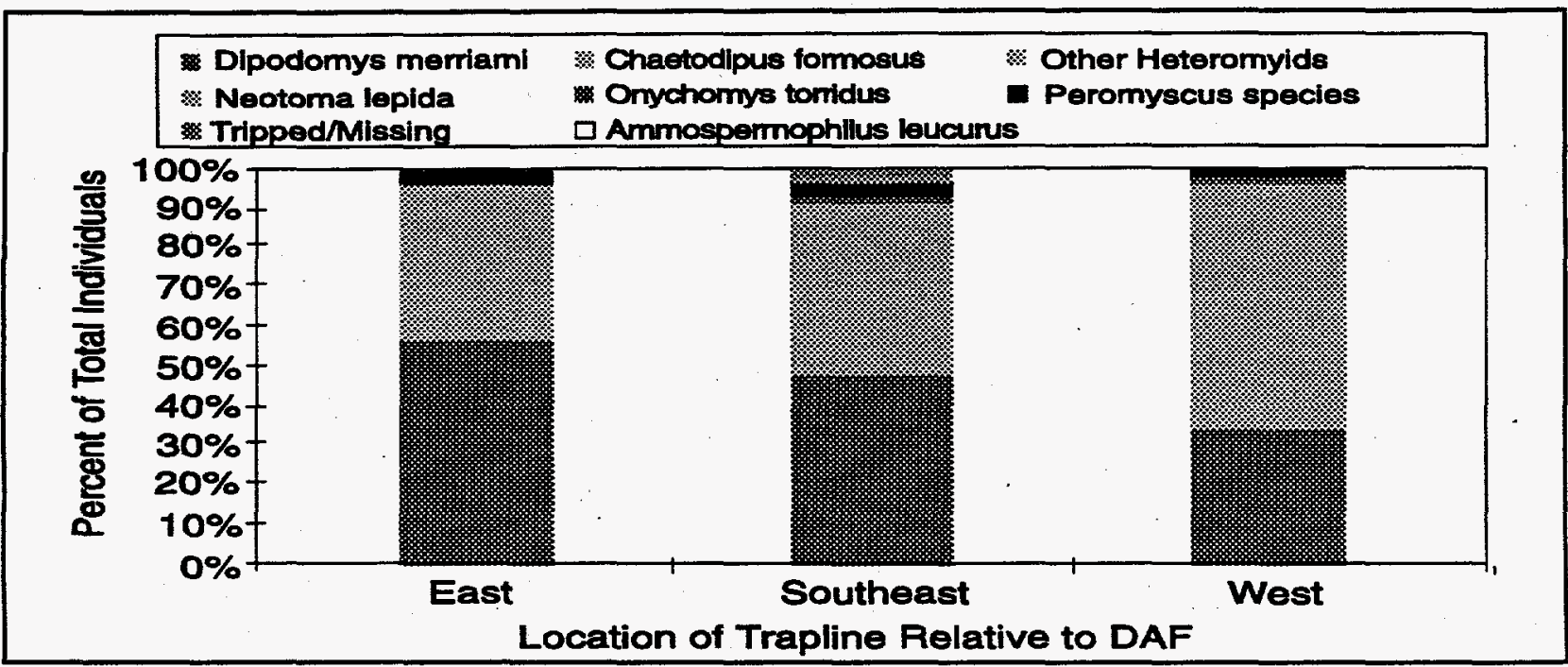

Figure 16. Relative abundance of small mammals at the DAF in 1993

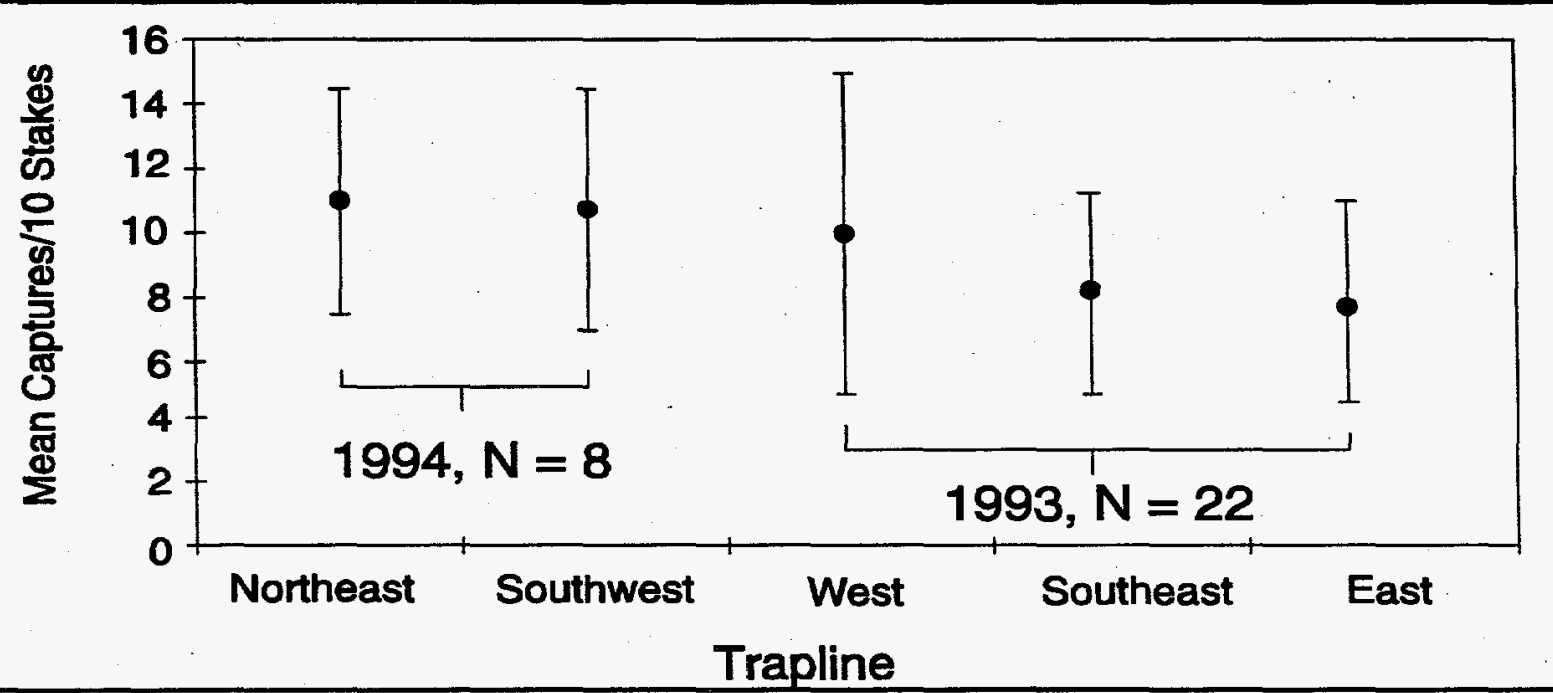

Figure 17. Mean capture \pm 2 se per 10 stakes in early June 1993 and 1994 at the DAF 


\section{Species of Special Concern}

No studies were undertaken in FY94 to determine the presence/absence of spotted bats (Euderma maculatum). This species generally is associated with rocky cliffs near forested areas but may venture into open desert scrub habitat during the summer months. While the DAF site does not include roosting habitat for spotted bats, bats could make sporadic visits to the sewage ponds. Not enough is known about the distribution of this species on the NTS (or in Nevada); however, it is documented as occurring in the vicinity of one artificial pond (now dry) on the NTS, approximately $50 \mathrm{~km}$ northwest of the DAF on Pahute Mesa (EG\&G/EM 1993).

\subsection{PERENNIAL PLANTS}

Monitoring of perennials around the DAF in 1994 had a primary goal of observing unexpected changes, as recommended in Woodward et al., 1995. Also intended was to detect expected changes, which included improved growth of perennials near the many DAF-related disturbances and establishment of new and perhaps weedy species in the disturbed areas. Because growth trends can be determined only after some time elapses, it was also an opportunity to determine preoperational trends in perennial plant size changes.

\subsection{METHODS}

Perennial plant transects marked in 1993 were remeasured on five sets of 20 plots arranged in concentric bands around the DAF. Five bands at 201-300 m, 301-400 m, 401-500 m, 501-600 $\mathrm{m}$, and 1-1.5 $\mathrm{km}$ each included twenty 10- $\mathrm{m}^{2}$ transects, with the outer ring expected to serve as control vegetation. A description of procedures for selecting the sites and parameters measured is in Woodward et al., 1995. Measurements were done as in 1993, with all plants lying within $1 \mathrm{~m}$ of a fiberglass tape measured and described. One species, Erioneuron pulchellum (desert fluffgrass, ERIPUL), was generally counted in each square meter and the median live and dead plants measured. A few single plants of Erioneuron pulchellum were measured individually to allow later monitoring of their growth. A few plants measured in 1993 were missing, no longer within the transect (a tape-positioning effect), or no longer attached to the ground. Such plants were not measured or recorded, though a note was made of reasons for deleting them.

One plot was within a newly fenced area around a building outside the main DAF security fence. The area was recently scraped and was considered for the purposes of this report to be bare. Intentions are not to sample that plot in the future, as it is considered inside the DAF security perimeter fence, and the BECAMP effort is intended to monitor effects on the ecosystem outside this fence. If monitoring continues, the plot should be replaced to maintain consistency in the study design.

Data analysis was done in Microsoft EXCEL, a change from 1993. Statistical tests (ANOVA, t-test) were done in EXCEL. Error terms in this report are \pm two standard errors unless otherwise noted. No attempt was made to check for normal distributions before calculation of 
error terms. The growth parameter $k(k=[\ln ($ volume $1 /$ volume 2$)] / \Delta t$ where $\Delta t=$ elapsed time in years) was calculated for plants whose volume was measured at both censuses, and which did not change from live to dead (or dead to live) between censuses. Standard errors for that parameter were normally based on numbers less than the whole population present in 1994 . Data were pooled into a single computer file, and analyzed on a plant-by-plant basis rather than by plot, except for analyses related to distance from the DAF.

Two species measured in the past with ephemeral plants were included in the perennial censuses in 1994. Both Eriogonum inflatum (desert trumpet, ERIINF) and Astragalus lentiginosus var. fremontii are short-lived herbaceous perennials that may live several years. If the DAF plots are monitored annually, valuable information on their growth and survival could be obtained with the perennial measurements.

Taxonomy of plants follows Munz (1974) with names updated following Kartesz and Kartesz (1982). Common names of plants follow Scott and Wasser (1980). The name change of Ceratoides lanata to Kraschennikova lanata follows Hickman (1993).

\subsection{RESULTS}

Population changes of perennial plants from 1993 - 1994 were generally minor. Most species were approximately constant in number, and volumes declined slightly (Table 4). Changes of a few plants can be expected due to variation in placement of the tape used to delimit the plots. In addition, a few plants are normally missed on a first census, and found at the next. These can explain most changes in number seen. However, there was a large decrease in numbers of Erioneuron pulchellum (Desert fluffgrass), a diminutive perennial grass that probably germinated in both 1992 and 1993, and possibly a significant decrease in numbers of Sphaeralcea ambigua.

Numbers of Erioneuron pulchellum declined 54 percent overall, which was reasonable considering the dry weather in 1994 and the small size and youth of the plants. There were differences in survival at different distances from the DAF (Table 5).

Survival of Erioneuron pulchellum was better near the DAF $(r=-0.917,3$ d.f., $P=0.03$ ). Detection of the now-dead plants in the dead grass population was erratic, and may indicate a problem with measurement of those numbers (Table 5).

One would expect mean size of Erioneuron pulchellum plants to mirror the survival data, such that mean size should increase more or decrease less where survival was better. This did not appear to be the case, as mean size of live plants decreased more nearer the DAF $(r=-0.3860, n=52, P=0.005$, Table 6).

In some respects the population of Sphaeralcea ambigua (desert globemallow, an herbaceous small shrub) behaved like Erioneuron puichellum, although involving only small numbers of plants. Numbers of Sphaeralcea ambigua increased from 12 to 15 near the DAF, but decreased from 28 to 16 far from it. Qualitatively, mean size was higher near the DAF both years (Table 7), but decreased markedly at all distances between 1993 and 1994. 
Table 4. Total live volumes (liters per $1000 \mathrm{~m}^{2}$ ) and numbers for perennial plant species found on one hundred $10-\mathrm{m}^{2}$ transects surrounding the DAF

\begin{tabular}{|c|c|c|c|c|}
\hline \multirow[b]{2}{*}{ Species and authority } & \multicolumn{2}{|c|}{$\begin{array}{l}\text { Live } \\
\text { volume }\end{array}$} & \multicolumn{2}{|c|}{ Numbers } \\
\hline & 93 & 94 & 93 & 94 \\
\hline Acamptopappus shockleyi Gray & 55 & 43 & 4 & 4 \\
\hline Ambrosia dumosa (Gray) Payne & 8,441 & 7,945 & 159 & 166 \\
\hline Astragalus lentiginosus var. fremontii (Gray) S. Wats. & - & 2 & - & 1 \\
\hline Atriplex confertifolia (Torr. \& Frem.) S. Watts & 689 & 512 & 39 & 32 \\
\hline Cactus (unidentified seedlings) & 0 & 0 & 0 & 3 \\
\hline Coleogyne ramosissima Torr. & 165 & 146 & 1 & 1 \\
\hline Dyssodia cooperi Gray & 1 & 1 & 1 & 1 \\
\hline Echinocereus engelmannii Parry & $<1$ & 0 & 1 & 0 \\
\hline Ephedra nevadensis S. Wats. & 4,427 & 4,434 & 8 & 9 \\
\hline Eriogonum inflatum Torr. \& Frem. & - & 103 & - & 23 \\
\hline Erioneuron pulchellum (H.B.K.) Tateoka & 355 & 90 & 5,831 & 2,676 \\
\hline Grayia spinosa (Hook.) Moq. & 607 & 357 & 7 & 6 \\
\hline Krameria parvifolia Benth. & 8,168 & 8,630 & 84 & 83 \\
\hline Kraschennikova lanata (Pursh.) A.D.J. Meeuse \& Smit. & 103 & 95 & 2 & 2 \\
\hline Larrea tridentata (Sesse \& Moc. ex DC.) Coville & 41,299 & 40,981 & 77 & 81 \\
\hline Lycium andersonii Gray & 2,287 & 2,095 & 27 . & 26 \\
\hline Menodora spinescens Gray & 331 & 320 & 16 & 16 \\
\hline Opuntia basilaris Engelm. \& Bigelow & 1 & 1 & 1 & 1 \\
\hline Opuntia echinocarpa Engelm. \& Bigelow & 116 & 92 & 6 & 6 \\
\hline Oryzopsis hymenoides (Roemer \& Schultes) Ricker & 1 & 1 & 22 & 20 \\
\hline Salazaria mexicana Torr. & 626 & 563 & 6 & 6 \\
\hline Sphaeralcea ambigua Gray & 4,274 & 165 & 106 & 98 \\
\hline Stephanomeria pauciflora (Torr.) Nutt. & 84 & 26 & 1 & 1 \\
\hline Stipa speciosa Trin. \& Rupr. & $<1$ & 1 & 1 & 1 \\
\hline Xylorhiza tortifolia (Torr. \& Gray) Greene & 74 & 22 & 1 & 1 \\
\hline Yucca brevifolia Engelm. & 22,813 & 19,391 & 5 & 5 \\
\hline
\end{tabular}


Table 5. Changes in numbers of Erioneuron pulchellum, and dead grasses (dominated by Erioneuron pulchellum) at different distances from the DAF, 1993-1994

\begin{tabular}{|l|c|c|c|c|c|c|}
\hline & \multicolumn{3}{|c|}{ Live } & \multicolumn{3}{c|}{ Dead } \\
\hline Distance & 1993 & 1994 & $\%$ Change & 1993 & 1994 & $\begin{array}{c}\% \\
\text { Change }\end{array}$ \\
\hline $0-300 \mathrm{~m}$ & 711 & 462 & -35 & 117 & 85 & -27 \\
\hline $301-400 \mathrm{~m}$ & 1442 & 1024 & -29 & 965 & 1313 & +36 \\
\hline $401-500 \mathrm{~m}$ & 1509 & 592 & -61 & 431 & 469 & +9 \\
\hline $501-600 \mathrm{~m}$ & 1253 & 504 & -60 & 776 & 1083 & +40 \\
\hline $1-1.5 \mathrm{Km}$ & 916 & 94 & -90 & 1166 & 530 & -55 \\
\hline
\end{tabular}

Table 6. Mean live size (liters \pm 2 se) and percent change in mean size of surviving Erioneuron pulchellum versus distance from the DAF, 1993-1994

\begin{tabular}{|c|c|c|c|}
\hline Distance & 1993 & 1994 & $\%$ Change \\
\hline $0-300 \mathrm{~m}$ & $0.054 \pm 0.022$ & $0.023 \pm 0.006$ & -57 \\
\hline $301-400 \mathrm{~m}$ & $0.067 \pm 0.028$ & $0.028 \pm 0.006$ & -58 \\
\hline $401-500 \mathrm{~m}$ & $0.078 \pm 0.030$ & $0.063 \pm 0.020$ & -19 \\
\hline $501-600 \mathrm{~m}$ & $0.056 \pm 0.021$ & $0.092 \pm 0.026$ & +64 \\
\hline $1000-1500 \mathrm{~m}$ & $0.014 \pm 0.005$ & $0.036 \pm 0.021$ & +157 \\
\hline
\end{tabular}

Table 7. Changes in numbers and mean size (liters \pm 2 se) of Sphaeralcea ambigua versus distance from the DAF, 1993-1994

\begin{tabular}{|l|c|c|c|c|c|c|}
\hline & \multicolumn{3}{|c|}{ Numbers } & \multicolumn{3}{c|}{ Mean Size } \\
\hline Distance & 1993 & 1994 & $\begin{array}{c}\% \\
\text { Change }\end{array}$ & 1993 & 1994 & $\begin{array}{c}\% \\
\text { Change }\end{array}$ \\
\hline $0-300 \mathrm{~m}$ & 12 & 15 & +25 & $82 \pm 82$ & $3 \pm 5$ & -96 \\
\hline $301-400 \mathrm{~m}$ & 6 & 6 & 0 & $4 \pm 4$ & $0 \pm 0$ & -98 \\
\hline $401-500 \mathrm{~m}$ & 25 & 24 & -4 & $72 \pm 42$ & $3 \pm 2$ & -96 \\
\hline $501-600 \mathrm{~m}$ & 35 & 37 & +6 & $37 \pm 17$ & $1 \pm 1$ & -97 \\
\hline $1000-1500 \mathrm{~m}$ & 28 & 16 & -43 & $6 \pm 4$ & $1 \pm 0$ & -91 \\
\hline
\end{tabular}


Rainfall in calendar 1994 was considerably lower than in 1993 (126 vs $275 \mathrm{~mm}$ at the Cane Springs monitoring station) and most perennial plants shrank. A logarithmic growth coefficient partially corrects for differences in growth rates among plants of different size (Erikson 1976). Plant shrinkage varied with distance from the DAF, with the greatest shrinkage nearer the DAF (Table 8) (ANOVA, $\left.F_{4,421}=2.94, P=0.020\right)$.

Vegetation parameters varied considerably with direction from the DAF. In 90 degree arcs centered on the cardinal directions, live perennial volume was lowest in the North and highest to the West of the DAF (Table 9). Shrinkage was greatest where live volume was highest, but differences in growth among directions were not statistically different (ANOVA, $\left.F_{3,417}=1.76, P=0.154\right)$.

Table 8. Mean growth coefficients ( $k$, defined in methods) \pm 2 se versus distance from the DAF

\begin{tabular}{|l|c|c|c|c|c|}
\hline & \multicolumn{5}{|c|}{ Distance, $\mathrm{m}$} \\
\hline Species & $0-300$ & $301-400$ & $401-500$ & $501-600$ & $1-1.5 \mathrm{~K}$ \\
\hline All & $-0.67 \pm 0.47$ & $-0.07 \pm 0.17$ & $-0.43 \pm 0.24$ & $-0.16 \pm 0.15$ & $-0.30 \pm 0.15$ \\
\hline AMBDUM & $-0.24 \pm 0.23$ & $+0.01 \pm 0.29$ & $-0.18 \pm 0.24$ & $+0.06 \pm 0.15$ & $-0.39 \pm 0.24$ \\
\hline KRAPAR & $+0.18 \pm 0.39$ & $+0.10 \pm 0.15$ & $+0.09 \pm 0.15$ & $+0.08 \pm 0.17$ & $+0.01 \pm 0.13$ \\
\hline LARTRI & $-0.10 \pm 0.29$ & $-0.08 \pm 0.14$ & $-0.03 \pm 0.10$ & $+0.09 \pm 0.09$ & $-0.02 \pm 0.08$ \\
\hline SPHAMB & $-3.96 \pm 2.15$ & $-2.29 \pm 3.14$ & $-3.77 \pm 1.02$ & $-2.32 \pm 0.87$ & $-1.99 \pm 0.99$ \\
\hline DEDSHB & $-0.03 \pm 0.24$ & $-0.26 \pm 0.19$ & $-0.19 \pm 0.15$ & $-0.18 \pm 0.14$ & $-0.30 \pm 0.11$ \\
\hline
\end{tabular}

\begin{tabular}{|c|c|c|c|c|c|c|c|c|}
\hline \multicolumn{2}{|c|}{ Table 9. Vegetative parameters at different directions from the DAF, 1994} \\
\hline $\begin{array}{c}\text { Area } \\
\left(\mathrm{m}^{2}\right)\end{array}$ & $\begin{array}{c}\# \\
\text { Live }\end{array}$ & $\begin{array}{c}\% \\
\text { Cover }\end{array}$ & $\begin{array}{c}\text { Volume } \\
\text { L100 } \\
\mathrm{m}^{2}\end{array}$ & $\begin{array}{c}\% \text { Dead } \\
\text { Volume }\end{array}$ & $\begin{array}{c}\% \\
\text { Dead } \\
\#\end{array}$ & $\begin{array}{c}\mathrm{k} \\
\pm 2 \mathrm{SE}\end{array}$ \\
\hline $\mathrm{N}$ & 200 & 13 & 101 & 8.7 & 4,228 & 61 & 43 & $-.08 \pm .14$ \\
\hline E & 250 & 11 & 165 & 10.8 & 6,777 & 59 & 29 & $-.20 \pm .16$ \\
\hline S & 300 & 16 & 203 & 14.7 & 7,956 & 38 & 26 & $-.34 \pm .19$ \\
\hline W & 250 & 15 & 116 & 14.3 & 14,506 & 48 & 29 & $-.44 \pm .22$ \\
\hline
\end{tabular}


Plants closer to disturbance were expected to grow faster. In 1994 plants in plots positioned within $10.1 \mathrm{~m}$ of a disturbance had significantly lower mean growth coefficients $(k=-0.59 \pm$ 0.26 ) than those farther from disturbance $(k=-0.18 \pm 0.09)$ (t-test, $t_{127}=-2.64, P=0.009$, assuming unequal variances).

Grazing did not appear to play a major role in perennial populations in 1994 . Three species had more than 10 percent of the sampled population grazed, Oryzopsis hymenoides (5 of 20 grazed from 10 to 90 percent), Eriogonum inflatum (6 of 23 grazed 15 to 30 percent), and Sphaeralcea ambigua (10 of 98 grazed 10 to 95 percent). Occasional woody shrubs showed evidence of minor grazing (10 to 60 percent).

Fruiting by perennials was low in 1994. In Erioneuron pulchellum 17 percent within $300 \mathrm{~m}$ of the DAF fruited, but less than 5 percent fruited at any greater distance. Among Larrea tridentata 53 of 81 plants bore fruit at sampling (65 percent). Totals of six Eriogonum inflatum, four Krameria parviflora, three Oryzopsis hymenoides, and three Sphaeralcea ambigua fruited in the whole sampled population.

\subsection{DISCUSSION}

Conditions of perennial plants near the DAF did not change greatly from 1993-1994, evidenced by similar population numbers and somewhat reduced live volumes (Table 3 , Woodward et al., 1995). The small shrinkage is consistent with observations elsewhere on the NTS, where live volumes have been found to correlate with four-year running mean rainfall (Hunter 1994c). The four-year mean in 1994 was approximately equal to that of 1993, as the added dry year 1994 balanced the lost dry year of 1990 . Mean rainfall for the years 19931994 was approximately equal to the 20 year annual mean, and vegetation should have been in approximate equilibrium both years. (Of course, evidence of the death of shrubs in 19891991 associated with drought [high ratio of dead to live plants] is present and expected to persist for many years.)

Removal of vegetation associated with DAF construction is expected to be the major factor causing changes in plant species composition, density and live volumes in the vicinity of the DAF. In other areas, shrub removal has resulted in improved growth of plants near disturbance. For example, plants on Yucca Flat and Mid Valley burned sites grew significantly faster than on adjacent control transects, and plants adjacent to 5-01 road in central Frenchman Flat grew faster than did control plants in undisturbed vegetation approximately $500 \mathrm{~m}$ distant (Hunter 1994). In addition, data from a Frenchman Flat borrow pit and a shrubremoval plot in Mercury suggest water builds up in the soil in the absence of shrubs (Romney et al., 1981; Hunter unpublished manuscript). Similar processes were expected near the DAF, but were not found. Plants nearer disturbance at the DAF grew significantly less (shrank more) than those far from disturbance.

At the present time, shrinkage of plants near the DAF is puzzling. The growth measurements are fairly coarse, as they are associated with measurement errors of about 20 percent for plant volume (Hunter, unpublished observations). Statistical significance depended on large numbers of measurements. One year of relatively slight growth/shrinkage is not ideal for detecting effects, and the finding of significant unexpected shrinkage near the DAF was therefore surprising. 
A mechanism of plant shrinkage near disturbed areas at the DAF is hard to imagine. Water should not have been as limiting near disturbance as in undisturbed desert. The absence of a significant directional effect on growth/shrinkage (Table 9) argues against a wind-dispersed factor. Prevailing winds on the NTS are primarily north-south (Black et al., 1994), and an inhibitor might have been expected to act in either one or both of those directions.

Radioactive clouds from above-ground weapons tests had strong directional effects as fallout killed vegetation in a narrow belt leading away from the ground zeroes (e.g. satellite photos in a report by Zimmerman et al. [1991]). Plants grow well near the paved surface of roads, indicating soil compaction and hydrocarbon vapors from oil or asphalt are not significantly harmful.

It should be noted that disturbance around the DAF is greater nearer the facility (Woodward et al., 1995), and hence the effects of the DAF itself are confounded by those of disturbance.

Mortality of Erioneuron pulchellum appeared to be reduced near the DAF, and fruiting of that species may have been enhanced. These are expected results of disturbance, so it appears the growth data were anomalous, but the mortality data were not.

We feel the perennial plant monitoring near the DAF should be continued as recommended in Woodward et al., 1995. An increased time-span of monitoring should improve detection and understanding of the growth effects. An increase in intensity of the effort does not seem warranted, although specific studies designed to explore the reduction in growth near DAF/disturbance might be useful. A better determination of the extent of the effect prior to the start of DAF operations might help distinguish preoperational from operational effects.

\subsection{EPHEMERAL PLANTS}

Poor germination of ephemeral plants in 1994 made extensive sampling pointless. Goals were to sample two points far from the DAF, as all 1993 plots were thought to be potentially affected by the extensive disturbance associated with DAF construction. One graveled area southwest of the DAF was sampled to determine if conditions there favored continuation of the high diversity seen in 1993. A scraped and compacted area west of the DAF was sampled to compare with the scraped and graveled area. Finally, the south edge of the paved road to the DAF was examined with the $\log _{10}$ technique used in 1993 in order to determine if the Schismus arabicus found invading along that road in 1993 was moving farther into the undisturbed vegetation.

\subsection{METHODS}

The two techniques used to sample ephemerals in 1994 were described in detail in Woodward et al., 1995. They were the standard BECAMP technique, which measures density within nested quadrats, the largest of which was $1000 \mathrm{~m}^{2}$. The technique was modified by counting plants in portions or the whole $100 \mathrm{~m}^{2}$ to get a rough density on some of the rarer species. The $\log _{10}$ technique involved estimating density of species observed in $1 \mathrm{~m}^{2}$ areas laid along a tape stretched perpendicular to the paved DAF roadway. It was modified in 1994 by 
improving the estimated log density to 1 decimal place below a log of 2 (100 plants $\left./ \mathrm{m}^{2}\right)$. In addition, a minimum density of 0.01 plants $/ \mathrm{m}^{2}(\log =-2)$ was used for all those found in any one square-meter quadrat. Eight rather than ten lines were examined in 1994.

Plant taxonomy followed Munz (1974) with synonymy provided by Kartesz and Kartesz (1980).

\subsection{RESULTS}

Ephemerals in the control transects were dominated in both sites by Bromus rubens, which was the only species common enough to fall in the quadrats totalling one-half square meter. All others of the 7 or 16 species were thus of low density. Numbers and biomass were greater on the plot to the North (20-5), where total shrub live volume was lower (Table 10).

On the two scraped areas west and southwest of the DAF, Bromus rubens was not dominant, but numbers, numbers of species present, and biomass produced were comparable to those on the undisturbed areas (Table 11). The scraped and graveled area (DAF2) was also sampled in 1993, when it had an unusually high number of species. In 1994 it again had relatively high diversity, and numbers were significantly increased over $1993\left(t_{38}=2.734\right.$, $P=0.009)$, though average plant weight and total biomass $\left(\mathrm{g} / \mathrm{m}^{2}\right)$ decreased. The scraped and compacted plot differed from the scraped and graveled plot in 1994, as both numbers $\left(t_{38}=3.31, P=0.002\right)$ and biomass $\left(t_{38}=2.26, P=0.03\right)$ were lower on the former.

Table 10. Summary statistics on two $1000-\mathrm{m}^{2}$ control transects; Plot 10-5 was at $1242 \mathrm{~m}$ South and 20-5 was $1197 \mathrm{~m}$ North of the DAF

\begin{tabular}{|l|c|c|}
\hline & $10-5$ & $20-5$ \\
\hline Total species in $1000 \mathrm{~m}^{2}$ & 16 & 7 \\
\hline Total species in $100 \mathrm{~m}^{2}$ & 11 & 2 \\
\hline Species in 20 quadrats & 1 & 1 \\
\hline Average species per quadrat \pm 2 se & $0.10 \pm 0.14$ & $0.5 \pm 0.2$ \\
\hline Bromus rubens $\mathrm{n} / \mathrm{m}^{2} \pm 2$ se & $6 \pm 9$ & $46 \pm 32$ \\
\hline Bromus rubens g/m ${ }^{2} \pm 2$ se & $0.06 \pm 0.10$ & $1.6 \pm 2.0$ \\
\hline Total $\mathrm{n} / \mathrm{m}^{2} \pm 2 \mathrm{se}$ & $6 \pm 9$ & $46 \pm 32$ \\
\hline Total g/m ${ }^{2} \pm 2$ se & $0.06 \pm 0.10$ & $1.7 \pm 2.0$ \\
\hline Average weight/plant $\mathrm{mg} \pm 2$ se & $10 \pm 2$ & $21 \pm 19$ \\
\hline Surface $\%$ rock \pm 2 se & $34.9 \pm 11.1$ & $67 \pm 15$ \\
\hline Surface $\%$ litter \pm 2 se & $19 \pm 9$ & $18 \pm 8$ \\
\hline Surface $\%$ shrub cover \pm 2 se & $23 \pm 18$ & $23 \pm 16$ \\
\hline Surface $\%$ mound \pm 2 se & $17 \pm 16$ & $22 \pm 17$ \\
\hline Rabbit pellets $\mathrm{n} / \mathrm{m}^{2} \pm 2$ se & $36 \pm 32$ & $10 \pm 8$ \\
\hline
\end{tabular}


Table 11. Summary statistics on two $1000-\mathrm{m}^{2}$ transects; DAF2 was on a scraped, graveled area southwest of the DAF, and plot 16-1 is on a scraped compacted area West of the DAF; DAF2 data are from the same location in 1993 and 1994; * $=$ the two plots differ in this parameter in 1994 at $p<0.05 ;{ }^{* *}=p<0.01$, d.f. $=38$.

\begin{tabular}{|c|c|c|c|}
\hline & \multicolumn{2}{|c|}{ DAF2 } & $16-1$ \\
\hline & 1993 & 1994 & 1994 \\
\hline Total species in $1000 \mathrm{~m}^{2}$ & 52 & 19 & 9 \\
\hline Total species in $100 \mathrm{~m}^{2}$ & 38 & 16 & 5 \\
\hline Species in 20 quadrats & 4 & 6 & 2 \\
\hline Avg. Species per quadrat $\pm 2 \mathrm{se}$ & $0.55 \pm 0.37$ & $0.71 \pm 0.21$ & $0.10 \pm 0.14$ \\
\hline Bromus rubens $\mathrm{n} / \mathrm{m}^{2} \pm 2 \mathrm{se}$ & $4 \pm 6$ & $2 \pm 4$ & $0 \pm 0$ \\
\hline Bromus rubens $\mathrm{g} / \mathrm{m}^{2} \pm 2 \mathrm{se}$ & $0.3 \pm 0.7$ & $0.003 \pm 0.007$ & $0 \pm 0$ \\
\hline Total $n / m^{2} \pm 2 s e^{* *}$ & $22 \pm 15$ & $62 \pm 36$ & $4 \pm 6$ \\
\hline Total $\mathrm{g} / \mathrm{m}^{2} \pm 2 \mathrm{se}^{*}$ & $7 \pm 10$ & $0.7 \pm 0.6$ & $0.04 \pm 0.05$ \\
\hline Average weight/plant $m g \pm 2 \mathrm{se}$ & $316 \pm 42$ & $11 \pm 5$ & $9 \pm 2$ \\
\hline Surface $\%$ rock \pm 2 se & $99.8 \pm 0.4$ & $100 \pm 0$ & $14 \pm 25$ \\
\hline Surface $\%$ litter $\pm 2 \mathrm{se}$ & $0.15 \pm 0.22$ & $3.0 \pm 2.2$ & $5.0 \pm 2.5$ \\
\hline Surface $\%$ shrub cover \pm 2 se & $0 \pm 0$ & $0 \pm 0$ & $3.8 \pm 7.5$ \\
\hline Surface $\%$ mound \pm 2 se & $0 \pm 0$ & $0 \pm 0$ & $0 \pm 0$ \\
\hline Rabbit pellets $n / m^{2} \pm 2 s e^{*}$ & $0 \pm 0$ & $22 \pm 16$ & $0 \pm 0$ \\
\hline
\end{tabular}

Rabbit pellets on the scraped and graveled area increased significantly from 0 in 1993 to $22 \pm 15$ in 1994. That is an indication of more palatable vegetation on the area.

Species present and approximate densities for all areas sampled in 1994 are in Table 12. Many species seen in 1993 were absent, and most present both years were at lower density in 1994.

Sampling of the roadside with the $\log _{10}$ technique provided results similar to those of 1993. First, in terms of species seen per area searched, it found more than on the $1000-\mathrm{m}^{2}$ transects ( $33 \mathrm{spp} . / 160 \mathrm{~m}^{2}$ versus a maximum of $\left.19 / 1000 \mathrm{~m}^{2}\right)$. Most species seen, as is normal, were of low density. As in 1993, Eriogonum deflexum was concentrated along the scraped road verge, and Bromus rubens was absent from that area. Schismus arabicus, an exotic weedy grass thought to be present because of the DAF construction, was found at low densities from 1 to $14 \mathrm{~m}$ from the pavement edge, and on one line at $35 \mathrm{~m}$ from the road. It was also found, as in 1993, on the two scraped areas near the DAF sampled in 1994, but not on the two control transects.

\subsection{DISCUSSION}

Several aspects of ephemeral populations around the DAF can be explained by reference to other NTS studies. Removal of shrubs has been shown to increase ephemeral densities and biomass (e.g., Hunter 1994d, Table 14; Hunter 1994e, Table 12). Introduced weedy species have historically been associated with disturbed areas (e.g., Beatley 1966), and Brandt and Rickard (1994) have recently suggested that only moderate disturbance is necessary to maintain them in the landscape. 


\begin{tabular}{|c|c|c|c|c|c|c|}
\hline \multirow{3}{*}{$\begin{array}{l}\text { Table 12. } \\
\text { SPECIES } \\
\text { s }\end{array}$} & \multirow{3}{*}{$10-5$} & \multirow{3}{*}{$20-5$} & \multirow{3}{*}{ DAF2 } & \multirow{3}{*}{$16-1$} & \multirow{2}{*}{\multicolumn{2}{|c|}{ ROAD }} \\
\hline & & & & & & \\
\hline & & & & & road & cont \\
\hline Astragalus acutirostris & & & & & 0.01 & 0.02 \\
\hline $\begin{array}{l}\text { Astragalus lentiginosus } \\
\text { fremontii }\end{array}$ & 0.01 & & 0.11 & $\bar{p}$ & 0.01 & 0.01 \\
\hline Bromus rubens & $6 \pm 9$ & $46 \pm 32$ & $2 \pm 4$ & 0.04 & 0.6 & 26.5 \\
\hline Bromus tectorum & & & & & 0.01 & 0.01 \\
\hline Calycoseris wrightii & & & $p$ & & 0.01 & 0.02 \\
\hline Camissonia brevicornu & $p$ & & $p$ & & 0.01 & 0.01 \\
\hline Caulanthus cooperi & & 0.02 & & & & \\
\hline Caulanthus lasiophyllus & & & & & 0.01 & 0.01 \\
\hline Chaenactis carphoclinia & 0.15 & & & & 0.01 & 0.02 \\
\hline Chaenactis stevioides & 0.01 & & 0.08 & & 0.01 & 0.01 \\
\hline Chorizanthe rigida & & & $2 \pm 4$ & & & \\
\hline Cryptantha circumscissa & & & & & 0.01 & 0.01 \\
\hline Cryptantha nevadensis & 0.06 & & 0.07 & & 0.01 & 0.04 \\
\hline Cryptantha pterocarya & 0.05 & & & & 0.01 & 0.02 \\
\hline Cryptantha recurvata & $p$ & & & & 0.01 & 0.01 \\
\hline Cryptantha virginensis & & $\mathbf{p}$ & & & & \\
\hline Descurainia pinnata & 0.01 & & 0.01 & & & \\
\hline Eriogonum deflexum & 0.03 & p & $46 \pm 37$ & $2 \pm 4$ & 1.7 & 0.9 \\
\hline Eriogonum inflatum & 0.03 & p & 0.08 & 0.04 & 0.01 & 0.03 \\
\hline Erodium cicutarium & & & & $p$ & 0.13 & 0.01 \\
\hline Eschscholtzia glyptosperma & & & 0.03 & & & \\
\hline Gilia transmontana & & & 0.02 & & 0.02 & 0.01 \\
\hline Ipomopsis polycladon & 0.01 & & 0.03 & & 0.01 & 0.01 \\
\hline Machaeranthera canescens & & $p$ & p & & & \\
\hline Malacothrix glabrata & & & 0.01 & & 0.01 & 0.01 \\
\hline Mentzelia albicaulis & $p$ & & 0.03 & & 0.01 & 0.04 \\
\hline Monoptilon bellioides & & & & & 0.01 & 0.01 \\
\hline Pectocarya platycarpa & & & & & 0.01 & 0.02 \\
\hline Phacelia fremontii & $p$ & & $2 \pm 4$ & $p$ & 0.01 & 0.02 \\
\hline Phacelia vallis-mortae & & & & & 0.01 & 0.01 \\
\hline Prenanthella exigua & & & & & 0.01 & 0.02 \\
\hline Rafinesquia neomexicana & & $p$ & & & & \\
\hline Salsola australis & 0.02 & & $6 \pm 12$ & 0.01 & 0.01 & 0.01 \\
\hline Schismus arabicus & & & $2 \pm 4$ & $2 \pm 4$ & 0.04 & 0.04 \\
\hline Sisymbrium altissimum & & & & $\mathrm{p}$ & & \\
\hline Stephanomeria exigua & $p$ & & & & & \\
\hline Vulpia octoflora & & & & & 0.03 & 0.03 \\
\hline
\end{tabular}


The high ephemeral diversity near the DAF may be associated with the low shrub densities and live volume. Ephemeral plants are sparse at higher altitudes on the NTS (e.g., Hunter 1994e, Table 6), in spite of greater rainfall, except on areas where the perennial plants have been removed, such as drill pads (e.g., Hunter 1994f, Table 9).

The introduced grass Schismus arabicus has been present on the NTS since the 1950s, but has not been common. It was not one of the common species found along the Mercury Highway in a study of roadside weeds in 1993 (Hunter 1994e). It was found to increase with summer irrigation (but not winter irrigation) on some plots in Mercury in the mid-1970s (Hunter et al., 1976, 1976 unpublished). It is a dominant grass in some warmer sandy areas of the Mojave Desert (Hunter et al., 1987). Given its seeming requirement for warmer weather than occurs on most of the NTS, its presence and expansion near the DAF may be related to the southern aspect and relatively low altitude of the DAF location.

Erodium cicutarium was present on the DAF roadside preferentially (Table 12), as was found in Hunter 1994 e for Mercury Highway.

The $\log _{10}$ technique, with the modifications in precision of estimates, worked well. Because it sampled plants over a relatively broad area, it was much better suited for detecting effects of the DAF and how far they might extend away from it than was the standard BECAMP technique. Use of a similar technique on lines radiating from the DAF instead of the paved road would be more likely to detect DAF-related damage, and the detection of more species with less search effort would be advantageous in light of the high species diversity of ephemeral populations near the DAF. It gives less precise data than the standard technique for common species, but those species are generally weedy and human influences on their populations are generally positive.

\subsection{CONCLUSIONS}

The DAF was still in a preoperational mode in 1994, with construction work largely restricted to the area inside the perimeter fence. Baseline studies in 1994, a dry year, largely support findings on DAF effects from 1993, a relatively wet year. To date, BECAMP has documented DAF environmental impacts on perennials, lizards, and birds. Perennials and lizards were removed from graded areas around the DAF buildings and from the road right of way. In 1993, bird use of the DAF sewage settling pond area was greater than that in nearby areas implying that the presence of this pond attracted more birds to this area.

The most notable difference between 1993 and 1994 was the 80 -fold reduction in bird use of the sewage settling pond in 1994. Apparently, water availability in this pond significantly enhances bird use of the general area only in years like 1993, a good to above average rainfall year. The dry conditions in 1994 also, apparently, curtailed bird reproduction in the DAF vicinity. In the absence of reproduction, males were not displaying at territory boundaries and the variable-circular-plot technique cannot be used. This suggests that estimation of DAF effects on birds (away from the sewage pond) will be difficult in drought years.

Small mammals, lizards, and plant populations vary a great deal near the DAF, such that abundances of several species differ greatly from one side to the other (Woodward et al., 1995, and this report). These differences have repercussions for assessing any changes that might arise from a nuclear mishap and radioactive breach of the DAF building complex, as they imply that directional differences in the flora and fauna occurred prior to the mishap. 
Thus, sample sites on different sides of the DAF would not represent suitable controls for comparison with downwind sites impacted by a radioactive breach of the building. This means that comparisons will need to be made between impacted sites and the same sites earlier that year or in prior years. 


\section{REFERENCES}

Beatley, J. C., 1966, "Ecological Status of Introduced Brome Grasses (Bromus spp.) in Desert Vegetation of Southern Nevada", Ecology 47:548-554.

Beatley, J. C., 1974, "Effects of Rainfall and Temperature on the Distribution and Behavior of Larrea Tridentata (Creosotebush) in the Mojave Desert of Nevada", Ecology 55(2):245-261.

Beatley, J. C., 1976, "Vascular Plants of the Nevada Test Site and Central-Southern Nevada: Ecologic and Geographic Distributions", Report TAD-26881, National Technical Information Service, U.S. Department of Commerce, Springfield, VA 22161, 308 pages.

Beatley, J. C., 1979, "Shrub and Tree Data for Plant Associations Across the Mojave/Great Basin Transition of the Nevada Test Site, 1963-1975", Report DOE/NV/2307-15, NTIS, U.S. Department of Commerce, 5285 Port Royal Rd., Springfield, VA 22161, 52 pp.

Black, S. C., H. Bruce Gillen and W. M. Glines, 1994, Introduction, pp 2-1 to 2-25 in Black, S. C., W. M. Glines, and Y. E. Townsend (eds.), "U.S. Department of Energy Nevada Operations Office Annual Site Environmental Report - 1993", Report DOE/NV/11432-123, available from the National Technical Information Service, U.S. Department of Commerce, 5285 Port Royal Road, Springfield, VA 22161.

Brandt, C. A. and W. H. Rickard, 1994, "Alien Taxa in the North American Shrub Steppe 4 Decades after Cessation of Livestock Grazing and Cultivation Agriculture", Biological Conservation 68(2):95-105.

EG\&G/EM (Energy Measurements, Inc.), 1993, "Yucca Mountain Biological Resources Monitoring Program Annual Report FY92", EG\&G/EM Santa Barbara Operations, Report No. 10617-2195.

Erickson, R. O., 1976, "Modelling of Plant Growth", Annual Review of Plant Physiology 27:407-434.

Hunter, Richard B., 1992, "Status of Perennial Plants on the Nevada Test Site in 1988", Pages 183-228 in Hunter, R. (Compiler), Status of the Flora and Fauna on the Nevada Test Site, 1988, Report DOE/NV/10630-29, available from the National Technical Information Service, U.S. Department of Commerce, 5285 Port Royal Road, Springfield, VA 22161.

Hunter, Richard B., 1994 a, "Trends in Perennial Plant Populations on the Nevada Test Site - 1989-1991", in Hunter, R. (Compiler), Status of the Flora and Fauna on the Nevada Test Site, 1989-1991, Report DOE/NV/11432-57, available from the National Technical Information Service, U.S. Department of Commerce, 5285 Port Royal Road, Springfield, VA 22161.

Hunter, R. B., 1994b, "Status of Perennial Plants on the Nevada Test Site, 1992", in R. Hunter

(Compiler) Status of the Flora and Fauna on the Nevada Test Site, 1992, Report DOE/NV/11432-58, available from the National Technical Information Service, U.S. Department of Commerce, 5285 Port Royal Road, Springfield, VA 22161. 
Hunter, R. B., 1994c, "Status of Perennial Plants on the Nevada Test Site, 1993", in R. Hunter (Compiler) Status of the Flora and Fauna on the Nevada Test Site. 1992, Report DOE/NV/11432-162, available from the National Technical Information Service, U.S. Department of Commerce, 5285 Port Royal Road, Springfield, VA 22161.

Hunter, R. B., 1994d, "Trends in Ephemeral Plant Populations on the Nevada Test Site. 1989-1991", Pages 334-K25 in R. Hunter (Compiler), Status of the Flora and Fauna on the Nevada Test Site, 1989-1991 Report DOE/NV/11432-57, NTIS, U.S. Department of Commerce, 5285 Port Royal Road, Springfield, VA 22161.

Hunter, R. B., 1994e, "Status of Ephemeral Plants on the Nevada Test Site in 1993", Pages 150-E215 in R. Hunter (Compiler), Status of the Flora and Fauna on the Nevada Test Site, 1993, Report DOE/NV/11432-162, NTIS, U.S. Department of Commerce, 5285 Port Royal Road, Springfield, VA 22161.

Hunter, R. B., 1994f, "Status of Ephemeral Plants on the Nevada Test Site, 1992", Pages 1-B33 in R. Hunter (Compiler), Status of the Flora and Fauna on the Nevada Test Site. 1992. Report DOE/NV/11432-58, NTIS, U.S. Department of Commerce, 5285 Port Royal Road, Springfield, VA 22161.

Hunter, R. B., E. M. Romney, A. Wallace, H. O. Hill, T. A. Ackerman and J. E. Kinnear, 1976, "Responses and Interactions in Desert Plants as Influenced by Irrigation and Nitrogen Applications", US/IBP Desert Biome Res.; Memo. 76-14. 7 pp.

Hunter, R. B.; E. M. Romney, J. E. Kinnear, T. L. Ackerman and H.O. Hill, (Unpublished manuscript), "Responses and Interactions in Desert Plants as Influenced by Irrigation and Nitrogen Applications", Report of 1976 progress, Manuscript in BECAMP Biological Data Repository, $43 \mathrm{pp}$.

Hunter, Richard, F. B. Turner, R. G. Lindberg and Katherine Bell Hunter, 1987, "Effects of Land Clearing on Bordering Winter Annual Populations in the Mohave Desert", Great Basin Naturalist 47(2):234-238.

Hunter, R. B. and P. A. Medica, 1989, "Status of the Flora and Fauna on the Nevada Test Site: Results of Continuing Basic Environmental Research. January through December 1987", Report DOE/NV/10630-2, NTIS, U.S. Department of Commerce, Springfield, VA 22161, 103 pp.

Kartesz, J. T. and R. Kartesz, 1980, "A Synonymized Checklist of the Vascular Flora of the United States. Canada, and Greenland", University of North Carolina Press, Chapel Hill, NC. 500 pp.

Munz, P. A., 1974, "A Flora of Southern California", University of California Press, Berkeley, CA. $1086 \mathrm{pp}$.

Reynolds, R. T., J. M. Scott and R. A. Nussbaum, 1980, "A Variable Circular-Plot Method for Estimating Bird Numbers", Condor 82:309-313. 
Romney, E. M., R. B. Hunter, and A. Wallace. 1981, "Vegetation Management and Recovery at Sites Disturbed for Solar Thermal Bower Systems Development", Report UCLA 12-1281, available from NTIS, U.S. Department of Commerce, Springfield, VA 22161, 21 pp.

Scott, T. G. and C. H. Wasser, 1980, "Checklist of North American Plants for Wildlife Biologists", The Wildlife Society, 7101 Wisconsin Ave, Washington, D.C. 20014, 58 pp.

Woodward, B., Hunter, P. Greger, and M. Saethre, 1995, "The 1993 Baseline Biological Studies and Proposed Monitoring Plan for the Device Assembly Facility at the Nevada Test Site", Report DOE/NV/11432-163, NTIS, U.S. Department of Commerce, Springfield, VA $22161,130 \mathrm{pp}$.

Zimmerman, P. D. N. K. Del Grande and W. McKinnis, 1991, "Persistent Changes in the Nevada Desert Resulting from Atmospheric Nuclear Tests", Unpublished manuscript held by R. Hunter. 


\section{DISTRIBUTION LIST}

Thomas K Ackerman, 528 Kendall Avenue, Apartment No. 5, Palo Alto, CA 94306

Becamp Library, Mercury, NV 89023, M/S 740 (5)

Brigham Young University Library, Exchange Section, Provo, UT 84601

Charles D Canham, Institute of Ecosystem Studies, New York Botanical Garden, Mary

Flagler Gary Arboretum, Box AB, Millbrook, NY 12545 (2)

Walter H Conley, Department of Biology, New Mexico State University, Las Cruces, NM 88003

Steve Corn, U.S. Department of Interior, Fish and Wildlife Service, 4512 McMurray Avenue, Fort Collins, CO 80525-3400

Death Valley National Monument, Library, Death Valley, CA 92328

M. E. DeMarre, Reynolds Electrical \& Engineering Co., Inc., Coordination and Information Center, Post Office Box 98521, M/S 548 (2)

John Donaldson, Regional Manager, Nevada Department of Wildlife, Region III, State Mailroom Complex, Las Vegas, NV 89158 (2)

Charles L Douglas, Department of Biological Sciences, University of Nevada Las Vegas, 4505 South Maryland Parkway, Las Vegas, NV 89154

EG\&G/EM, Library, M/S 570/C-52 (2)

Donald R. Elle, Director, Environmental Protection Division, DOE Nevada Operations Office, Post Office Box 98518, Las Vegas, NV 89193-8518, M/S 505 (2)

Todd Esque, National Biological Service, C/O BLM Dixie Research Area, 225 N Bluff Street, St George, UT $84770^{\circ}$

Edward H Essington, Los Alamos National Laboratory, Environmental Science Group, HSE 12, Los Alamos, NM 87545

Fred Ferate, Reynolds Electrical \& Engineering Co., Inc., Analytical Services Department, Post Office Box 98521, Las Vegas, NV 89193-8521, M/S 776

Bert Friesen, Raytheon Services Nevada, Post Office Box 98518, Las Vegas, NV 89193-5487, M/S 584

Thomas H Fritts, U.S. Fish and Wildlife Service, National Museum of Natural History, Smithsonian Institution, Washington DC 20560 


\section{Distribution List, cont.}

Robert Furlow, U.S. Department of Energy, Nevada Operations Office, Post Office Box 98518, Las Vegas, NV 89193-8518, M/S 505

Richard O Gilbert, Batelle Pacific Northwest Laboratories, Post Office Box 999, Richland, WA 99352

Wayne Glines, Reynolds Electrical \& Engineering Co., Inc., Environmental Information Center, Post Office Box 98521, Las Vegas, NV 89193-8521, M/S 412

Global Environmental Monitoring System, Post Office Box 30552, Nairobi, Kenya

Ron Green, EG\&G/EM, Post Office Box 1912, M/S 570/V-01, Las Vegas, NV 89125

Paul Greger, EG\&G/EM, Post Office Box 1912, M/S 570N-01, Las Vegas, NV 89125

Ross Haley, Nevada Department of Wildlife, 4747 Vegas Drive, Las Vegas, NV 89158

Mike Hess Acting Chief, Game Division, Nevada Department of Wildlife, 1100 Valley Road, Post Office Box 10678, Reno, NV 89520

Richard Hunter, EG\&G/EM, Post Office Box 1912, M/S 570/V-01, Las Vegas, NV 89125 (2)

Clive D Jorgensen, Brigham Young University, Department of Zoology, 574 Widtsoe Building, Provo, UT 84602

Teri A Knight, Nevada Heritage Program, Barrick Museum of Natural History, University of Nevada Las Vegas, 4505 South Maryland Parkway, Las Vegas, NV 89154

Kevin R. Krenzien, Reynolds Electrical \& Engineering Co., Inc., Analytical Services Department, Post Office Box 98521, M/S 708, Las Vegas, NV 89193-8521

Alan R. Latham, Reynoids Electrical \& Engineering Co., Inc., Analytical Services Department, Post Office Box 98521, M/S 708, Las Vegas, NV 89193-8521

John M. Mcgrail, U.S. Department of Energy, NTSO, M/S 701, Mercury, NV 89023 (2)

Philip A Medica, U.S. Department of Interior, National Biological Survey, P O Box 26569, Las Vegas, NV 89126 (2)

Stephen A. Mellington, DOE Nevada Operations Office, Post Office Box 98518, M/S 505, Las Vegas, NV 89193-8518

Wesley E Niles, Department of Biological Sciences, University of Nevada Las Vegas, 4505 South Maryland Parkway, Las Vegas, NV 89154

Thomas P O'farrell, 511 Avenue H, Boulder City, NV 89005 


\section{Distribution List, cont.}

John Oldemeyer, National Ecology Research Center, 4512 McMurray Aavenue,

Ft Collins, CO 80525-3400 (2)

Kent Ostler, EG\&G/EM, Post Office Box 1912, M/S 570/V-01, Las Vegas, NV 89125

Susan Peck, EAD, USEPA Environmental Systems Monitoring Lab, Post Office Box 93478, Las Vegas, NV 89193-3478

Lonnie C. Pippin, Desert Research Institute, Social Sciences Center, Post Office Box 60220, Reno, NV 89506

David Rabrock, Special Collections Library, University of Nevada Las Vegas, 4505 Maryland Parkway, Las Vegas, NV 89154

Daniel Rakestraw, EG\&G/EM, Post Office Box 1912, M/S 570/V-01, Las Vegas, NV 89125

W. H. Rickard, 1904 Lassen Avenue, Richland, WA 99352

Evan M Romney, 1736 East Gary Street, Mesa, AZ 85203

Edward F. Rucker, U. S. Department of Energy, NTS Area 6, M/S 219 (3)

Mary Saethre; EG\&G/EM, Post Office Box 1912, M/S 570/N-01, Las Vegas, NV 89125

Terry Sexson, U S Department of Interior, Fish and Wildlife Service, Office of Information Transfer, 1025 Pennock Place Suite 212, Fort Collins, CO 80524

Sid Sloan, Bureau of Land Management, Post Office Box 26529, Las Vegas, NV 89126

L. S. Sygitowicz, Reynolds Electrical \& Engineering Co., Inc., Environmental Management Division, Post Office Box 98521, M/S 612, Las Vegas, NV. 89193-8521

United Nations Environment Programme, Post Office Box 30552, Nairobi Kenya

University of Nevada Las Vegas, Library, Special Collections, 4505 South Maryland Parkway, Las Vegas, NV 89154

U.S. Bureau of Land Management, District Manager Las Vegas, District Office, Post Office Box 26569, Las Vegas, NV 89126

Technical Information Resource Center, Nevada Operations Office, U.S. Department of Energy, Post Office Box 98518, Las Vegas, NV 89193-8518, M/S 505

U.S. Department of Energy, Office of Scientific and Technical Information, Technical Center, Post Office Box 62, Oak Ridge, TN 37831 